\title{
Türkiye Üniversitelerinde İnsan Hakları Derslerine ve Çalışmalarına İlişkin Niceliksel Bir İnceleme
}

\author{
Seda Kalem \\ Istanbul Bilgi Üniversitesi Hukuk Fakültesi, Hukuk Felsefesi ve Sosyolojisi Anabilim Dalı. Adres: Eski Silahtarağa Elektrik Santrali Kazım Karabekir Cad. \\ No: 2/13 34060 Eyüpsultan/Istanbul \\ ORCID: S. Kalem (0000-0002-2404-9429)
}

\begin{abstract}
Özet
Bu çalıșma, Ağustos 2017-Şubat 2018 zaman diliminde gerçekleștirilen “Türkiye’de Yükseköğretimde İnsan Hakları Öğreniminin Durumu" araștırma projesinin bulgularına dayanmaktadır." Projenin amacı, üniversitelerin hukuk fakültelerinde ve siyasal/kamu programlarında verilen lisans ve yüksek lisans dersleri ile bu üniversitelerdeki araştırma merkezlerinin çalıșmaları üzerinden insan hakları alanındaki akademik bilgiye ilișkin kapsamlı bir veri tabanı oluşturmaktır. Türkiye'de insan hakları eğitimi özellikle 1990lı yıllardan itibaren gerek kamu bürokrasisi içerisinde gerek sivil toplumda gerekse akademik çevrelerde giderek artan bir ilgi görmüștür. Bu eğitim faaliyetleri ağırlıklı olarak çeşitli gruplara yönelik farkındalık artırma ve bilgi ve beceri kazandırma faaliyetleri olarak karşımıza çıkar. Öte yandan, insan haklarının gençlerin eğitiminde bir sosyal sorumluluk ve toplumsal bilinç geliștirme yöntemi olarak nasıl kullanıldığına yönelik çalışmalar ise bu eğitimin ilk-orta ve lise seviyesindeki durumuna odaklanır. İnsan haklarının yükseköğretim müfredatındaki yerine, bu alanda üretilen bilginin niceliğine ve niteliğine ilişkin çalışmaların ise yok denecek kadar az olduğu görülür. Bu bağlamda, makaleye konu olan çalışma tam da bu boşluğu doldurmak için öncelikli olarak bir mevcut durum tespiti araştırması olarak tasarlanmıştır. Bu bağlamda çalışma öncelikli olarak niceliksel bilgiler barındırmakla beraber, Türkiye'de yükseköğretimde insan hakları alanında üretilen ve paylaşlan bilginin niteliğine ve etkilerine ilişkin yapılacak daha derinlemesine çalıșmalara da ıșık tutacaktır. Bu makalede sadece siyasal bilimler/kamu yönetimi bölümlerindeki ve üniversitelerdeki insan hakları merkezlerindeki durum değerlendirilecek, hukuk fakülteleri ise başka bir çalıșmanın konusu olacaktır.
\end{abstract}

Anahtar Kelimeler: İnsan hakları eğitimi; insan hakları araştırmaları; yükseköğretimde insan hakları; Türkiye'de insan hakları eğitimi

*Bu proje, Raoul Wallenberg Insan Hakları ve Insancıl Hukuk Enstitüsü Türkiye Programı tarafından desteklenen bir araştırma projesidir. Proje Dr. Seda Kalem Berk ve Dr. Kasım Akbaş tarafından yürütülmüştür. Orjinal rapor da RW Enstitüsüne teslim edilmek üzere iki yazarlı olarak hazırlanmıştır.

\section{A Quantitative Study on Human Rights Education and Research at Turkish Universities}

\begin{abstract}
This article is based on the findings of the "Türkiye'de Yükseköğretimde İnsan Hakları Öğreniminin Durumu” research project that was carried out in the period of August 2017-February 2018. The main objective of the project was to create a database of academic knowledge on human rights through an examination of courses at law faculties and political science departments and activities of research centers. In Turkey, particularly since 1990s, human rights education has received significant attention within public bureaucracy, civil society and academia. This education, however, has mostly been in the form of awaraness raising, capacity increasing activities for different groups. Studies that focus on the use of human rights education as a method for increasing social responsibility among young people, on the other hand, mostly focus on primary, middle and high school students. This reveals the scarcity of works on the role of human rights education in higher learning. As a baseline study, this article is an inital attempt to fill this gap with large-scale quantitative information that allows us to map out the current state of human rights education in academia. This quantitative introduction intends to pave the way for more qualitative studies on the content, the methods and the impact of human rights courses and projects in higher learning. In this article, data on political science departments and research centers will be covered and law faculties will be the focus of another piece.
\end{abstract}

Keywords: Human rights education; human rights Research; human rights in higher education; human rights education in Turkey

*Yazışma Adresi / Address for Correspondence:

Seda Kalem, Email: seda.kalem@bilgi.edu.tr

Geliş Tarihi / Received Date: 19.06.2019

Kabul Tarihi / Accepted Date: 12.08 .2019

Doi: 10.26701/uad.579963

\section{GiRiș}

Bilgiye dayalı olmadan geliştirilen politikalar hangi alanda olursa olsun verimsiz sonuçlar ortaya koyma ve bu nedenle de emek, zaman ve kaynak israfina neden olma tehlikesini taşır. Türkiye'de özellikle yasal düzenlemelerin 
sosyal bilim yöntemleriyle elde edilmiș verilere dayanmadan geçirilmesi ve sahadaki ihtiyaçlar tespit edilmeden politikalar üretilmesi sık rastlanılan durumlardır (Elveriş, Jahic ve Kalem, 2007). Esasen, her türlü sosyal, ekonomik, siyasi politikanın işlerlik kazanabilmesi için öncelikle var olan durumun bilimsel esaslarla araştırılması gerekir. Kuşkusuz bu durum eğitim ve öğretim politikaları için de geçerlidir. Gerek zorunlu eğitim gerekse yükseköğretime ilişkin yapılacak düzenlemelerin, mevcut durumun ihtiyaçlarını tespit etmek için gerçekleştirilen araştırmalara dayandırılması önemlidir.

Özellikle yükseköğretim alanının hem meslek edinme üzerindeki katkısı hem de kişilerin tüm sosyal, siyasi ve kültürel refahını şekillendirmedeki gücü nedeniyle iyi yapılandırılmış olması gerekir (Cooper, 2013; Easterbrook, Kuppens ve Manstead, 2016; Egerton, 2002; Ehrlich, 2000; $\mathrm{Ma}$, Pender ve Welch, 2016). Bir diğer deyişle, akademik ve alt yapısal yeterliği yüksek üniversitelerde sunulan, erişilebilir ve dünya standartlarında geçerli olabilecek kalitede bir yükseköğretim sadece bireysel fayda değil toplumsal ve kültürel artı değer de üretebilir. Böyle bir yüksek öğretimin teknik bilgi üzerinden mesleki formasyon kazandırmanın ötesinde, eleştirel düşüncenin yöntemlerini öğretmesi, bireyin muhakeme yeteneklerini geliştirmesi ve toplumsal meselelere karşı farkındalığını artırması da beklenir. Bu çerçevede, üniversite ve dengi kurumlarda öğrenim gören bireylerin genel olarak toplumsal ve siyasi meselelere karşı duyarlılıklarının daha yüksek olduğu, bu bireylerin gönüllü çalışmalar üzerinden toplumsal değişimin etkin katılımcıları olmalarının daha olası olduğu ileri sürülür (Egerton, 2002; McMahon, 2009).

Bu bağlamda, insan hakları alanı bu türden bir ahlaki ve toplumsal bilincin geliştirilmesinde ve bireylerin sosyal sorumluluk üstlenmelerinde özellikle etkili olabilecek bir alandır (Andreopoulos, 1997; United Nations Educational, Scientific and Cultural Organization [UNESCO], 1968, 1987). İnsan hakları eğitiminin çatışma çözümünde, sürdürülebilir barışın inşasında, sosyal adaletin içsellleştirilmesinde, kalkınma politikalarının geliştirilmesinde ve dezavantajlı grupların güçlendirilmesinde kilit rol oynadığı ileri sürülür (Andreopoulos ve Claude, 1997). Bu sebeplerden ötürü insan hakları alanındaki bilginin ne şekilde üretileceği esasen bu hakların kullanımına ilişkin bir değeri de taşımaktadır. Bir diğer deyişle, haklara dair edinilecek bilginin hakların kullanımı konusunda bir farkındalığı da doğurması beklenir. Bu beklenti doğrultusunda da özellikle soğuk savaș sonrası dönemde insan hakları eğitimi uluslararası politikanın önemli bir unsuru haline gelmiştir.

Örneğin Birleşmiş Milletler [BM] tarafından 1995-2004 yılları arasında sürdürülen ve insan hakları kültürünü küresel çapta geliştirmeyi hedefleyen $B M$ İnsan Hakları Eğitimi için On yıl (1995-2004) sürecinde Türkiye'nin de içinde bulunduğu yaklaşık 90 ülkede insan haklarına ve temel özgürlüklere ilişkin farkındalığın ve saygının artı- rılmasına yönelik faaliyetler sürdürülmüștür (United Nations Office of the High Commissioner for Human Rights [OHCHR], t.y.a). Bu dönemin kazanımlarını takiben 2005 yılında da "insan hakları eğitiminin temel prensipleri ve yöntemlerine ilişkin ortak bir anlayışın teşvik edilmesi, eylem için sağlam bir çerçevenin çizilmesi ve uluslararası seviyeden tabana her türlü ortaklığın ve işbirliğinin güçlendirilmesi" hedefleri doğrultusunda BM İnsan Hakları Eğitimi Dünya Programı başlatılmıştır. BM Genel Kurulu tarafından başlatılan ve $B M$ İnsan Hakları Eğitimi için On yll sürecinin aksine bitiş tarihi olmayan Program'ın ilk evresinde ilk ve ortaokul düzeyinde insan hakları eğitiminin geliştirilmesine yönelik çalışmalar yürütülmüş, ikinci evresinde ise özellikle yükseköğretime odaklanılmıştır (OHCHR, t.y.b). Benzer bir şekilde BM İnsan Hakları Yüksek Komiserliği de, insan haklarının ancak bireylerin ve toplumların bu hakların korunması konusunda "bilgilendirilmiş ve sürekli” bir talep ortaya koymaları durumunda mümkün olabileceğini ileri sürer (OHCHR t.y.c.). Tam da bu nedenle, insan hakları eğitiminin ortaya koyacağı değerlerin esas amacının bireyleri hem kendi haklarına hem de başkalarının haklarına sahip çıkma konusunda cesaretlendirmek olduğuna işaret edilir. Komiserlik, insan hakları eğitiminin yaygınlaştırılması konusunda bir yandan devletlere ve sivil toplum kuruluşlarına destek sağlarken, aynı zamanda kendi bünyesinde de insan hakları eğitimine yönelik materyaller hazırlamakta ve bu alanda kullanılabilecek araçları geliştirmektedir.

Aynı doğrultuda Uluslararası Af Örgütü de bireylerin kendi toplumlarında ve tüm dünyada eşitlik ve haysiyet gibi değerlere sahip çıkmalarını sağlayacak becerilerini geliştirmek konusunda insan hakları eğitiminin önemine işaret eder (Uluslararası Af Örgütü [UAÖ], t.y.). UAÖ’nün öğretmenlere yönelik olarak hazırladığı, ilk ve ortaöğretim ile lise ve dengi okullarda çocuklara ve gençlere yönelik olarak verilecek insan hakları eğitiminin genel kavramsal çerçevesini ve yöntemini çizdiği İlk adım: İnsan Hakları Eğitimine Başlangıç için El Kitabı isimli yayını da böyle bir eğitimin ortaklaştırılarak yaygınlaşmasına katkıda bulunur (2002). Aynı zamanda UAÖ insan hakları eğitimleri ile ilgili faaliyetlerini yaygınlaştırmak için 2004 yılından itibaren İnsan Hakları Eğitimi Eylem Programını da başlatmıştır. Avrupa Konseyi tarafından çocuklar ve gençler arasında insan haklarına sahip çıkma bilincinin yerleşmesi ve bir insan hakları kültürünün oluşması için geliştirilen Compass: Manual for Human Rights Education with Young People da bir insan hakları eğitimi el kitabı olarak Türkçe dâhil birçok dile çevrilmiş önemli bir kaynaktır (2002).

Benzer şekilde, uluslararası düzeyde insan hakları eğitiminin güçlendirilmesi ve yaygınlaştırılması konusunda faaliyetler yürüten Global Coalition for Human Rights Education [HRE 2020] isimli sivil toplum işbirliği de kaliteli ve bütünsel bir eğitimin bireylere sağlayacağı bilgi ve beceri ile onları "gündelik hayatta insan haklarını teşvik etme, savunma ve uygulama" hususlarında güçlendirece- 
ğini ileri sürer. Bu bağlamda, Türkiye'den Kadının İnsan Hakları Yeni Çözümler Derneğinin de içinde yer aldığı 15 ülkeden bağımsız örgütün bir araya gelerek oluşturduğu HRE 2020, insan hakları eğitimini örgün eğitimin içine yerleștirerek haklarını talep etme konusunda daha bilinçli vatandaşların yetiştirilmesine katkıda bulunmayı hedefler (HRE 2020, t.y.). Bu çerçevede 2015 yilında tüm resmi eğitim kurumlarında -yükseköğretim dâhil olmak üzere- insan hakları eğitiminin ne șekilde ve ne kalitede yer aldığını ölçmek adına bir de çerçeve kaynak geliştirilmiştir. Bu kaynak ile sivil toplum kuruluşları, resmi makamlar, ulusal insan hakları örgütleri ve/veya BM mekanizmaları tarafından sağlanan eğitimlerin karşılaștırılarak iyileștirilmesi hedeflenmiştir (HRE 2020, 2015).

Küresel gelişmelere paralel şekilde 1990larla birlikte Türkiye'de de insan haklarının uluslararası politikadaki önemi farkedilmeye başlanmış ve özellikle de idareden kaynaklanan ihlallere yönelik yargı dışı yeni mekanizmalar getirilmiştir (Açık, 2011, s. 96). 1990ların şiddet ortamının Türkiye Cumhuriyeti devletinin insan hakları siciline olumsuz etkileri de bu tür mekanizmaları stratejik olarak önemli kılar (Altıparmak, 2007, s. 55). Bu bağlamda ilk olarak 1990 yllında TBMM bünyesinde bir İnsan Hakları İnceleme Komisyonu kurulmuş, hemen ardından da insan hakları devlet bakanlığı düzeyinde idari teşkilata dahil edilmiştir.

2000li yıllarla birlikte ise insan hakları alanının gerek devlet kurumları nezdinde gerekse sivil toplum ve akademik çalışmalar bağlamında giderek daha görünür olmaya başladığını, aktivizm bileșeninin yanında insan haklarına yönelik kuramsal ve metodolojik bir ilginin de arttığını söylemek mümkündür. Bu durum, Türkiye'nin yeni yüzyıla Avrupa Birliği üyelik tartışmalarının şekillendirdiği bir siyasi atmosferde girmesiyle de ilgilidir. Bu dönemde gerek uyum yasaları çerçevesinde yapılan anayasal ve yasal düzenlemeler gerekse yeni kurulan insan hakları mekanizmaları temel hak ve özgürlüklerin korunarak güçlendirilmesine yönelik önemli adımlardır. 2001 yılında Başbakanlık Teşkilatı Kanununda yapılan değişiklikler ile kurulan İnsan Hakları Başkanlığı, İnsan Hakları Üst Kurulu, İnsan Hakları İhlal İddialarını İnceleme Heyetleri ile İnsan Hakları Danışma Kurulu gibi yapılar bu dönemde insan haklarının devlet içinde kurumsallaşmasının örnekleridir. Benzer şekilde, 2012 yılında kurulan Türkiye İnsan Hakları Kurumu ${ }^{1}$ ve Kamu Denetçiliği Kurumu da idarenin işlemlerinin insan haklarına uygunluk bakımından denetlenmesi bağlamında önemli yapılardır. ${ }^{2}$

Bu gelişmelere insan hakları eğitimi özelinde bakıldığında ise 1998 yılında $B M$ İnsan Hakları Eğitimi için On Yıl (1995-2004) kapsamında kurulan ve BM Insan Haklart Eğitimi Dünya Programı amaçları doğrultusunda çalışmalar yapması planlanan İnsan Hakları Eğitimi Ulusal

${ }^{1} 2016$ yılında yapılan değişiklikle Türkiye Insan Hakları ve Eşitlik Kurumu ismini almıştır.

${ }^{2}$ Çalışmanın esas olarak insan hakları eğitimine odaklanıyor olmasından ötürü bu kurumlara dair bir etkililik tartışması kapsam dışı bırakılmıştır.
Komitesinin resmi kurumlar nezdinde atılan ilk önem adım olduğu söylenebilir (OHCHR, t.y.a.). Aynı yıl, Milli Eğitim Bakanlığı sekizinci sınıflardaki Vatandaşlık Bilgileri derslerini de BM'in talepleri doğrultusunda $\mathrm{Va}$ tandaşlık ve İnsan Hakları Eğitimi dersleri ile değiştirir (Sen ve Starkey, 2017). 1999 yllında ise Komite tarafından hazırlanan ve 1998-2007 yıllarını kapsayan İnsan Hakları Eğitimi Türkiye Programı yayımlanmıștır. ${ }^{3}$ 2011-2015 döneminde ise $\mathrm{AB}-\mathrm{AK}$ ortak projesi olarak geliştirilen $\mathrm{De}$ mokratik Vatandaşlık Eğitimi ve İnsan Hakları Eğitimi Projesi ile özellikle ilk ve orta öğretimde demokrasi kültürü ve insan haklarına ilişkin farkındalığın yerleştirilmesi için çeşitli eğitim faaliyetleri yürütülmüştür. 2015-2016 öğretim yılında ilkokul dördüncü sınıflarda okutulmak üzere müfredata eklenen İnsan Hakları, Yurttaşlık ve Demokrasi dersinin geliștirilmesi bu projenin en önemli çıktısı olarak görülür. Resmi birimler tarafından yürütülen faaliyetler dışında, 1990ların ortasından itibaren insan hakları eğitiminin sivil toplum kurum ve kuruluşlarının çalışmalarında da giderek artan bir şekilde yer aldığı görülmektedir. Örneğin UAÖ Türkiye Şubesi insan hakları alanında yürüteceği eğitim faaliyetleri için üç farklı kaynak geliştirir. Kadına yönelik şiddetin engellemesi için çalışan aktivistlere yönelik geliştirilen kaynağın dışındaki iki kaynak da ilköğretim, lise ve dengi okullarda görev yapan ögretmenlerin insan hakları konusundaki bilgi ve becerilerini geliștirmelerine yönelik hazırlanır (UAÖ, 2002, 2010). Tarih Vakfı da 2002 yllından beri farklı ortaklarla yürüttüğü Ders Kitaplarında İnsan Hakları Projesi ile ilk ve ortaöğretimde okutulan ders kitaplarının insan hakları çerçevesinden değerlendirilmesine ve müfredatın bu şekilde iyileştirilmesine katkıda bulunmuştur. 2013-2014 yıllarında yürütülen üçüncü projede 245 ders kitabı niteliksel insan hakları ölçütüne göre taranmış ve hazırlanan rapor ilgili tüm kurum ve kuruluşlarla paylaşılmıştır.

$\mathrm{Bu}$ gelişmelere paralel olarak insan hakları eğitimi 1990lardan itibaren akademik çalışmaların da konusu olmaya başlar. Gülmez'in 1996 tarihli Türkiye'de Insan Hakları Eğitimi Çalışmalarına Toplu Bakış isimli çalışmasının yanı sıra Büyükkaragöz ve Kesici'nin 1998 tarihli Demokrasi ve İnsan Hakları Eğitimi kitabı ve Karaman Kepenekçi'nin 1999 tarihli Türkiye'de Genel Ortaöğretim Kurumlarında İnsan Hakları Eğitimi başlıklı yayımlanmamış doktora tezi bu alanda üretilen ilk çalışmalardandır. Türkiye'de insan hakları eğitimi alanında yapılan akademik çalışmaların esasen iki koldan ilerlediği öne sürülebilir. Kimi çalışmalar bu eğitimin nasıl olması gerektiği üzerine yoğunlaşan daha öğretici metinler iken (Gürkaynak, Türkeli ve Bağll, 2002; Turan, 2017) çoğu çalışma da mevcut eğitimi anlamaya, değerlendirmeye ve hatta zaman zaman dönüştürmeye yöneliktir. Bu ikinci gruptaki çalışmaların konularına göre ayrıca sınıflandırılması da mümkündür. Şöyle ki, insan hakları eğitimine ilişkin gö-

\footnotetext{
3 Programda, ilk, orta ve lise ile üniversite öğrencileri insan hakları eğitimlerinin temel hedef gruplarından sayılmış ise de bu öğrencilere yönelik ne gibi faaliyetler yürütüldüğüne ve bunların sonucunda ne gibi kazanımlar olduğuna ilişkin güncel bir bilgi bulunmamaktadır (İnsan Hakları Eğitimi On Yılı Ulusal Komitesi, 1999).
} 
rece genel değerlendirmeler yapan çalışmaların yanı sıra (Gülmez, 1996) daha özel olarak bu eğitimin demokrasi ile gerek kavramsal gerekse mevcut dersler üzerinden ilişkisini kuran çalışmalar (Büyükkaragöz ve Kesici, 1998; Gülmez, 2001; Gündoğdu, 2004) ile hem müfredatın (Karaman Kepenekçi, 2011; Ünal, 2012) hem de ders kitaplarının (Bağlı ve Esen, 2003; Çayır, 2003, 2014; Çotuksöken, Erzan ve Silier, 2003; Karaman Kepenekçi, 2003, 2005a) insan hakları perspektifinden değerlendirmesini yapan çalışmalar da bulunmaktadır. Aynı zamanda bazı araştırmalar da öğretmenlerin ve öğrencilerin bu derslere ve kitaplara ilişkin algılarına odaklanır (Çayır ve Bağlı, 2011; Dolanbay, 2016; Gürel, 2016; Gürtan ve Tüzün, 2005; Karaman Kepenekçi, 2005b).

Şu halde Türkiye'de insan hakları eğitimi üzerine gerek kamu bürokrasisi gerekse sivil toplum tarafından yürütülen projelerin ve bu alanda yapılan akademik çalışmaların ağırlıklı olarak belirli meslek gruplarına, aktivistlere ve öğrencilere yönelik farkındalık artırma ve bilgi ve beceri kazandırma faaliyetlerine odaklandıkları söylenebilir. Ek olarak, derslerin ve ders kitaplarının içerik açısından insan hakları prensipleri bağlamında değerlendirildiği çalışmaların da ağırlıklı olarak ilk, orta ve lise seviyesine odaklandığı, insan haklarının yükseköğretim müfredatındaki yerine, bu alanda üretilen bilginin niceliğine ve niteliğine ilişkin çalışmaların ise yok denecek kadar az olduğu görülür. Bu makale tam da bu boşluğu doldurmak yönünde atılan bir adımdır. Bu hedef doğrultusunda ilerleyen bölümlerde Türkiye üniversitelerinin siyaset bilimi/kamu yönetimi programlarında verilen ve insan hakları alanıyla ilgili olduğu düşünülen dersler ile insan hakları alanında çalışan araştırma merkezlerinin faaliyet alanlarına ilişkin kapsamlı bir tarama çalışması sunulacaktır.

Türkiye üniversitelerinde siyasal/kamu bölümlerinde verilen insan hakları derslerine ve insan hakları merkezlerinde yürütülen araştırma ve projelere ilişkin genel bir resim çizmek ilk etapta bu alanın boyutunu, sınırlarını ve içeriğini anlamak adına önemlidir. Nasıl ki ilk-orta ve lise düzeyinde verilen insan hakları eğitimi üzerine yapılan araştırmalar, bu eğitimin sınırlılıklarını ortaya koyarak iyileştirilmesine katkıda bulunabilir ise, benzer bir katkı yükseköğretimde insan haklarına ilişkin derslerin araştırıldığı bir çalışmadan da beklenebilir. Aynı zamanda bu araştırmanın çizeceği genel tablo bu alanda çalışan akademisyenlerin ve araştırmacıların deneyim paylaşımlarını da mümkün kılacaktır. Farklı üniversitelerde verilen derslerin, yürütülen projelerin bir haritasının çıkarılması daha paylaşımcı bir akademik ortamın oluşmasına katkıda bulunabilir. Ek olarak böyle bir çalışma, insan hakları alanına dair bilginin salt eğitim odaklı olmaktan çıkarılıp, öğretim amaçlı olarak ne şekilde kullanılabileceğine ve bu tür bir öğretimin ne gibi etkileri olabileceğine ilişkin daha kapsamlı çalışmaların da önünü açabilir. Son olarak, mevcut haliyle niceliksel bir tarama çalışması olan bu araştırmanın, Türkiye akademisinde insan hakları denilince öğretim üyelerinin ve öğrencilerinin ne anladığını, bu derslerden ne gibi beklentileri olduğunu, bu akademik alanın kimler tarafından hangi önceliklerle belirlendiğini ve bu seçimlerin siyasi gelişmelerden ve mevcut ideolojik/ politik yapıdan nasıl etkilendiğini ortaya koyacak daha niteliksel çalışmalarla desteklenmesi de amaçlanmaktadır. ${ }^{4}$

\section{YÖNTEM}

Bir tarama çalışması olarak tasarlanan araştırma projesi kapsamında nicel teknikler kullanılarak üç alanda mevcut bilgiye erişilmesi hedeflenmiştir:

- Hukuk fakültelerinde lisans ve lisansüstü/doktora seviyelerinde verilen insan hakları dersleri hakkında bilgiler

- Siyaset/kamu vb. bölümlerinde lisans ve lisansüstü/ doktora seviyelerinde verilen insan hakları dersleri hakkında bilgiler

- İnsan hakları alanında çalışan merkezlere, bu merkezlerde çalışanlara ve yürütülen faaliyetlere ilişkin bilgiler.

$\mathrm{Bu}$ hedefler kuşkusuz öncelikli olarak bazı sınırlamaları ve tanımlamaları gerekli kılmıştır. İnsan hakları alanı, gerek kapsamındaki konular ve dersler bağlamında gerekse akademik nitelikte değerlendirilebilecek faaliyetler bağlamında çeşitlilik göstermektedir. Dolayısıyla, bu alanda verilen derslere ve yürütülen faaliyetlere ilişkin oluşturulacak bir veri tabanı ilk olarak bu alanın tanımlanmasını gerektirmiştir. Sosyal bilimlerde her tanım kaçınılmaz olarak araştırmacıların öznel seçimlerinin ürünüdür. Bu seçimler araştırmacıların epistemolojik yaklaşımlarından, kendi biyografilerinden, araştırma tecrübelerinden ve mesleki eğilimlerinden etkilendiği kadar, araştırmanın zaman ve kaynaklar bakımından sınırlılıklarından da etkilenir. Bu tür bir seçim, bu proje bağlamında iki soruyu dikkate almayı gerekli kılmıştır. Bunların ilki "insan hakları derslerini ve faaliyetlerini nerelerde arayacağı" sorusudur ve kapsama ilişkindir. İkincisi ise, "insan hakları derslerini ya da faaliyetlerini nasıl belirleyeceğiz" sorusudur ve bu da tanımlamaya ilişkin bir sorudur.

İlk meseleyle ilişkili olarak, araştırmanın hem söz konusu zaman dilimi içerisinde gerçekleştirilebilmesi hem de elde edilecek verinin karşılaştırılabilir olması adına, çalışılacak alanın kapsamının hukuk fakülteleri ve siyaset/kamu programlarıyla sınırlandırılması uygun bulunmuştur. İnsan hakları alanı gerek kuramsal çerçevesi bağlamında (Kuçuradi, 2018) gerekse aktivizm biçiminin hak ihlallerinin takibinde ve bu ihlallerle mücadelede olağan hak arama yollarına eş değer bir öneme sahip olması açısından, hukuk alanı ile ilişkisi görünür bir alandır (Kalem ve Akbaş, 2018). Dünyada da bu alanın yükseköğretimde ilk ortaya çıktığı bölümler hukuk fakülteleri olmuştur (Maran, 1997, s.196). Bu noktadan hareketle, projeye Türkiye'de hukuk fakültesi olan tüm üniversiteler dâhil edilmiş-

\footnotetext{
${ }^{4}$ Az sayıda da olsa insan hakları eğitiminin siyasi gelişmeler ve yerleşik bürokratik kültür bağlamında politik/ideolojik/kültürel analizini yapan çalısmalar da vardır (Babül, 2017; Çayır, 2008; Sen ve Starkey, 2017). Ancak bunların arasında yükseköğretimdeki duruma odaklanan çalışmaya rastlanmamıştır.
} 
tir. Aynı zamanda, insan hakları alanıyla ilgili olabilecek derslere en fazla siyaset/kamu bölümlerinde rastlanacağ düşüncesinden hareketle, bu programlar da araştırmaya dâhil edilmiştir. Öte yandan, çalışmayı sadece fakültelerle sınırlandırmak, özellikle araştırmalar ve projeler bağlamında üretilen bilginin yok sayılması anlamına geleceğinden, insan hakları alanında çalışan (proje yürüten, araştırma yapan, konferans vb. etkinlikler düzenleyen, eğitim veren) merkezlerin ve benzeri birimlerin faaliyetleri de akademik çalışmalar olarak değerlendirilmiştir. Projede bu üç alandaki durum ortaya konulmuş olmakla birlikte, bu makalede hukuk fakülteleri kapsam dışı bırakılmıştır. ${ }^{5}$ Çalışmanın bundan sonraki kısmı sadece siyasal/kamu yönetimi bölümlerine ve merkezlere odaklanacaktır.

Araştırmada hangi derslerin ve faaliyetlerin insan hakları alanı ile ilgili sayılacağı konusu ise bir tanımlamayı gerekli kılmıştır. Netice itibarıyla, bu çalışma ile alanın bir topografisinin oluşturulması hedeflendiği için, araştırma kapsamına alınacak derslerin ve faaliyetlerin de net bir biçimde insan haklarına ilişkin olmaları koşulundan yola çıkılmıştır. Bir başka ifadeyle, öncelikli olarak adında insan hakları geçen, konu başlığından insan hakları alanıyla ilişkisi net olarak anlaşılabilen dersler ve çalışmalar derlenmiştir. Aynı zamanda, isminde doğrudan insan hakları ibaresi geçmemekle birlikte, temel haklara ve hak arama mekanizmalarına ilişkin dersler de içerikleri kontrol edilmek suretiyle insan hakları dersleri olarak değerlendirilmiştir. ${ }^{6}$ Örneğin Temel Hak ve Özgürlükler isimli bir ders doğrudan insan hakları dersi kategorisinde kodlanmıștır.

Öte yandan, insan hakları gerek epistemolojik gerekse metodolojik olarak birçok farklı disiplini, özellikle de hukuk ile sosyal bilimleri birleştirebilen bir çalışma alanıdır (Coomans, Grünfeld ve Kamminga, 2009; Maran, 1997). Bu ortaklık temel hak ve özgürlükler, ayrımcılık ya da toplumsal cinsiyet eşitsizliği gibi bazı konularda daha görünür olmakla birlikte, özellikle 20. yüzyılın son çeyreğinden itibaren, hukuka eleştirel yaklaşımların da katkısıyla, daha farklı alanları ve grupları kapsayacak şekilde gelişmiştir. Bugün çevre, çocuk, göç, sağlık, bilişimim gibi alanlar insan hakları öğreniminde kurucu rol üstlenmeye başlamışlardır. ${ }^{7}$ Bu nedenle çalışmada, insan hakları, insan hakları hukuku, temel hak ve özgürlükler, Avrupa

\footnotetext{
Hukuk fakültelerine ilişkin bulguların analizi Dr. Kasım Akbaş tarafından yapılmıştır. Bu analiz bu makaleye dâhil edilmemekle birlikte, projenin RW ile paylaşılan kapsamlı raporunda yer almaktadır. Bilgi için kakbas@gmail.com.

${ }^{6}$ Bu çerçeve, Kuçuradi'nin "insanın olanaklarının gerçekleştirilebilmesi” ile ilgili hak ve özgürlükler tanımlaması üzerinden düşünülebilir (2018, s. 58-59).

${ }^{7}$ Günümüzde bu genişlemenin ortaya çıkardığı olumsuz etkiler bile tartışıı hale gelmiştir. Örneğin Freedman, İnsan Hakları Evrensel Beyannamesinin (IHEB) kabul edildiği 1948 yılından beri insan hakları alanının temel olarak üç başıkta genişlediğini ileri sürer: insan hakları koruma mekanizmalarındaki sayısal artış, insan hakları kavramına ve anlamına ilişkin yapılan düzenlemelerde ve içtihatlardaki artış ve dezavantajlı ya da kırılgan gruplara yönelik özel koruma mekanizmalarındaki artış (2018). Bu tespitinin hemen arkasından ise artışın ve genişlemenin her zaman olumlu sonuçlar doğurmadığını ileri sürer. Bu bağlamda, özellikle de IHEB'in kapsadığı temel hak ve özgürlüklerin ötesinde yeni hak alanları ve mekanizmaları yaratma, insan olmaktan kaynaklı haklar olan bu hakların alanını bireyin dışına ve ötesine taşıma ve mevcut insan haklarının ihlal edilmesi pahasına yeni hak alanları oluşturma çabalarının sakıncalarına dikkat çeker (Freedman, 2018).
}

Insan Hakları Sözleşmesi, Avrupa İnsan Hakları Mahkemesi ve benzeri başlıktaki dersler temel insan hakları dersleri olarak kodlanırken, toplumsal cinsiyet, çevre/ kent, göç ve azınlıklar konulu dersler de alt insan hakları dersleri olarak nitelendirilmiştir. ${ }^{8}$ Bu kapsam ve tanımlar dâhilinde, 138 siyaset/kamu/uluslararası ilişkiler bölümü ${ }^{9}$ ile hukuk fakültesi ve/veya kamu/siyaset bölümlerinden birine sahip üniversitelerde bulunan toplam 162 insan hakları merkezinin tamamı bu çalışmanın konusunuoluşturmaktadir.

Araştırmada veri kaynağı olarak ise üniversitelerin internet siteleri kullanılmıștır. Bu seçim günümüzde bütün kurumlar gibi üniversitelerin de tanıtımlarını internet üzerinden yapmalarıyla ilgilidir. Bu tanıtım özelllikle de vakıf üniversiteleri için önemlidir zira bu kurumlar devlet üniversitelerine göre daha fazla rekabetçi piyasa koşulları içinde yarışmak durumundadırlar. Bu nedenle esasen internet siteleri üniversitelerin öğrencilere ne vaat ettiklerini görünür ve erişilebilir kıldıkları mecralardır. Bu sayfalarda, Bologna sürecinin de bir gereği olarak, üniversiteler ve bölümler hakkında genel bilgilerin dışında, akademik kadro, verilen derslerin içeriği, bu derslerin zorunlu mu yoksa seçmeli mi olduğu ve bu derslerin beklentileri gibi daha detaylı bilgilere de ulaşmak mümkündür. Bu çerçevede üniversitelerin internet siteleri Ekim-Kasım 2017 tarihleri arasında taranmış ve Excel tablosuna işlenerek veri haline getirilmiştir (Kalem ve Akbaş, 2018).

Üniversitelerin internet sitelerindeki mevcut bilgiler nesnel ve açıça erişilebilir veriler olmakla birlikte bu sitelerin temel kaynak olarak alınması bazı sıkıntıları da beraberinde getirmiştir. Özellikle de sitelerde yeterli bilgi bulunmaması veya mevcut bilginin yetersiz olması da veri toplama sürecini zaman zaman zora sokmuştur. Öte yandan, sayfaların güncellenmemiş olmalarından dolayı erişilen bilgilerin mevcut durumu yansıtmadığı örneklerle de karşılaşılmıştır. Örneğin bazı sayfalarda 20 Temmuz 2016'da ilan edilen Olağanüstü Hal çerçevesinde geçirilen kanun hükmünde kararnameler ile ihraç edilen öğretim elemanları tarafından verilen derslere rastlanmıştır (Kalem ve Akbaş, 2018). ${ }^{10}$ Aynı zamanda, tarama birden fazla araştırmacı tarafından gerçekleştirildiği için, insan hakları derslerine ilişkin bir şablon çıkarılmış olsa dahi, şablon dışında kalan derslerin de olduğunu ve bunların dahil edilip edilmeyeceğine ilişkin kararın da taramayı yapan araştırmacılar tarafından verildiğini de belirtmek gerekir. Bu nedenle bazı derslerin araştırma asistanlarının yorumlarına göre şablon dışında bırakılması söz konusu olmuş olabilir. Bu da araştırmanın yöntemsel bir sınırlılığı

\footnotetext{
${ }^{8}$ Alt insan hakları nitelemesi haklar alanında bir hiyerarşiye işaret etmekten ziyade özel hak alanlarını belirgin kılmak adına başvurulan bir gruplamaya işaret etmektedir. Terimin Ingilizce karşılığı "subfield"dir.

92017 yılı itibarıyla faaliyette olan 185 üniversitenin içinde siyaset/kamu/uluslararası ilişkiler bölümleri olan üniversitelerin sayısı ise 138'dir ve bu üniversitelerin tamamı incelenmiştir (Yükseköğretim Kurulu, t.y.). Bu listeye, 20 Temmuz 2016 Olağanüstü Hal ilanını takiben çıkarılan kanun hükmünde kararnamelerle kapatılan üniversiteler ile Kıbrıs üniversiteleri dâhil değildir.

${ }^{10}$ Bu makale yayımlandığı sırada burada paylaşılan verilerin değişmiş olması ihtimali de söz konusudur.
} 
olarak not edilmelidir.

Son olarak, bulgularla ilgili iki önemli hatırlatmada bulunmakta fayda vardır. Çalışma bu haliyle bir tarama çalışması olduğu için niteliksel bir derinliğe sahip değildir. Bu sebeple taramaya dahil edilen derslerin tamamının fiilen veya etkileri bağlamında insan hakları dersleri sayılıp sayılamayacağı sorusu bu yöntem ile cevaplanabilecek bir soru değildir. Benzer şekilde, yukarıda bahsedilen sebeplerden ötürü bu çalışma kapsamına alınmamış olan insan hakları dersleri olması da güçlü bir olasılıktır. Çalışmanın bu alanda verilen tüm dersleri eksiksiz kapsadığı gibi bir iddiası yoktur (Kalem ve Akbaș, 2018).

\section{BULGULAR ${ }^{11}$}

Çalışma kapsamında, Türkiye'nin 138 üniversitesindeki kamu yönetimi, siyaset bilimi ve uluslararası ilişkiler ${ }^{12}$ programları taranmış ve bu programlarda temel insan hakları ve alt insan hakları alanlarında verilen dersler incelenmiştir. Hacettepe Üniversitesi bu alanlarda en fazla programa sahip üniversitedir. İstanbul, Çanakkale, Dokuz Eylül ve Marmara Üniversiteleri hemen arkasından gelmektedir. Üniversitelerin türlerine göre bir karşılaştırma yapıldığında ise, kamu/siyaset/UAİ programlarının sayıca en fazla devlet üniversitelerinde bulunduğu görülmektedir. Bu durum, devlet üniversitelerinin kontenjanlarının vakıf üniversitelerine göre daha yüksek olmasıyla açıllanabilir.

\subsection{Programlar}

Kamu/siyaset/UAİ alanlarında lisans, yüksek lisans ve doktora seviyelerinde toplam 434 program bulunmuştur. Bu programlar, isimlerindeki farklılıklara -kamu yönetimi, siyaset ve kamu, uluslararası ilişkiler vb.-, lisans, yüksek lisans ve doktora seviyesinde olup olmamalarına ve Türkçe ya da İngilizce -hatta az sayıda da olsa bazı durumlarda Fransızca- olup olmadıklarına bağlı olarak değişen 29 kategoride toplanmıştır. Daha sonra analiz kolaylığı sağlaması için, bu kategoriler Lisans, Yüksek Lisans ve Doktora olarak üç temel başlık altında incelenmiştir. Tablo 1.0 orjinal 29 program ismini gösterir.

Analiz kolaylığı açısından, karma kategorisinde kodlanan 18 program kapsam dışı bırakıldığında, geriye kalan 416 programın içinde toplam 207 tane lisans seviyesinde kamu yönetimi ve benzeri program olduğu görülmektedir. Bu sayı, toplam program sayısının yaklaşı \%49'una denk gelmektedir. Bir diğer ifadeyle, kamu/siyaset/uluslararası ilişkiler bölümlerindeki programların yaklaşık yarısı lisans seviyesindeki programlardan oluşmaktadır.

Aynı zamanda, bu alanda toplam 138 tane yüksek lisans programı, 71 tane doktora programı olduğu görülmektedir. Yüksek Lisans ve Doktora programlarının toplamı, bu

${ }^{11}$ Çalışmanın bundan sonraki bölümü kamu yönetimi, siyaset bilimi ve uluslararası ilişkiler programları ile merkezleri kapsayacaktır.

${ }^{12}$ Bundan sonra UAi.
Tablo 1. Kamu/Siyaset/UAI Lisans/YL/Doktora Programları

\begin{tabular}{|c|c|}
\hline Program adı & Program adedi \\
\hline Kamu Yönetimi Lisans & 27 \\
\hline Kamu Yönetimi Yüksek Lisans & 28 \\
\hline Public Administration MA & 1 \\
\hline Kamu Yönetimi Doktora & 16 \\
\hline Public Administration PhD & 1 \\
\hline Siyaset ve Kamu Lisans & 64 \\
\hline Political Science and Public Administration BA & 6 \\
\hline Siyaset ve Kamu Yüksek Lisans & 28 \\
\hline Siyaset ve Kamu Doktora & 13 \\
\hline Uluslararası İlişkiler Lisans & 57 \\
\hline International Relations BA & 8 \\
\hline Uluslararası İlişkiler Yüksek Lisans & 48 \\
\hline Uluslararası İlişkiler Yüksek Lisans İng. & 3 \\
\hline Uluslararası Ilişkiler Doktora & 25 \\
\hline International Relations PhD & 2 \\
\hline Siyaset Lisans & 2 \\
\hline Political Science BA & 1 \\
\hline Siyaset Yüksek Lisans & 6 \\
\hline Siyaset Doktora & 4 \\
\hline Political Science PhD & 1 \\
\hline Siyaset ve Uluslararası İlişkiler Lisans & 38 \\
\hline Siyaset ve Uluslararası İlişkiler Lisans İng & 4 \\
\hline Siyaset ve Uluslararası İlişkiler Yüksek Lisans & 19 \\
\hline Siyaset ve Uluslararası Ilişkiler Doktora & 8 \\
\hline Siyaset ve Uluslararası Ilişkiler Doktora İng. & 1 \\
\hline Toplumsal Cinsiyet Yüksek Lisans & 3 \\
\hline Kent ve Çevre Yüksek Lisans & 1 \\
\hline Yönetişim ve Sivil Toplum Kuruluşları Yüksek Lisans & 1 \\
\hline Karma * & 18 \\
\hline
\end{tabular}

Bazı durumlarda programın hangi düzeyde sunulduğu ya da kamu yönetimi mi siyaset bilimi mi ya da uluslararası ilişkiler bölümü mü olduğu anlaşıımamıştır. Örneğin bazı programların sayfalarında Siyaset Bilimi ve UAI Lisans/Siyaset Bilimi ve Kamu Yönetimi Lisans gibi başıılar görülmüştür. Bu nedenle bu tür programlar "karma" olarak kodlanmıştır.

alandaki tüm programların yaklaşık \% 51'ini oluşturmaktadir.

\subsection{Dersler}

Araştırma kapsamına dahil edilen toplam 434 kamu/ siyaset/UAİ lisans ve yüksek lisans/doktora programında insan hakları alanı ile ilgili olabilecek lisans ve yüksek lisans/doktora derslerine ayrıca bakıldığı zaman ise, bu alana dâhil edilebilecek toplam 745 dersin 124 ayrı üniversitede verildiği görülmüştür. Bu toplam 745 dersin üniversitelerarası dağılımına bakıldığında, Dokuz Eylül Üniversitesi sunduğu toplam 34 insan hakları dersi ile listenin başında yer alır. Bu derslerin 28 tanesinin alt insan hakları alanına ait dersler olduğu ve lisans seviyesinde alt insan hakları alanlarında verilen beş dersin dışında, geriye kalan 29 dersin hepsinin seçmeli olduğu görülmektedir. Çanakkale Üniversitesindeki dersler için de benzer bir durum söz konusudur. Buradaki toplam 26 dersin de sadece beş tanesi temel insan hakları alanı dersleridir. Tüm derslerin içinde zorunlu olarak verilen sadece iki ders vardır ve bunlar lisans seviyesinde verilen İnsan Hakları ve Demokrasi dersi ile Çevre Yönetimi ve Politikası dersidir. Sayıca en fazla derse sahip olan üçüncü 
üniversite ise 23 ders ile Bartın Üniversitesidir. Burada da lisans seviyesinde verilen üç dersin dışında geriye kalan 20 ders seçmeli derslerdir.

Öte yandan, Türkiye'nin en büyük ve akademik prestiji yüksek devlet üniversitelerinde ise kamu/siyaset/UAI bölümlerinde gerek lisans gerekse yüksek lisans ve doktora programlarında mevcut insan hakları derslerinin sayıca az olduğu görülmektedir. Bunlar arasında Ankara Üniversitesi 15 ders ile görece yüksek bir sayıya sahip olmakla birlikte, Marmara (9), ODTÜ (8) ve Hacettepe (7) üniversitelerinde verilen ders sayısı kontenjanlarına kıyasla az sayılabilir. İstanbul Üniversitesi ise sadece dört ders ile insan hakları alanında oldukça eksik bir müfredata sahip bir üniversite görüntüsü çizmektedir. Öte yandan, Türkiye'nin en eski vakıf üniversitesi ünvanını taşıyan İhsan Doğramacı Bilkent Üniversitesinde ise kamu/ siyaset/UAİ bölümlerinin sadece lisans programlarında beş tane insan hakları dersi verildiği de tespit edilmiştir. Tüm bu derslerin hesaplanmasına, bazı derslerin -özellikle de yüksek lisans ve doktora programlarında- ufak değişiklikler dışında aynı dersler olabileceği ve/veya aynı öğretim elemanları tarafından veriliyor olabilecekleri de akılda tutulmalı, ders çeşitliliği bu husus göz önünde bulundurularak değerlendirilmelidir. Örneğin Dokuz Eylül Üniversitesinde tüm seviyelerde verilen çevre ve kent alanlarındaki derslerin neredeyse tamamı aynı öğretim üyesi tarafından verilmektedir. Şekil 1. toplam 745 dersin programlara göre dağılımını gösterir.

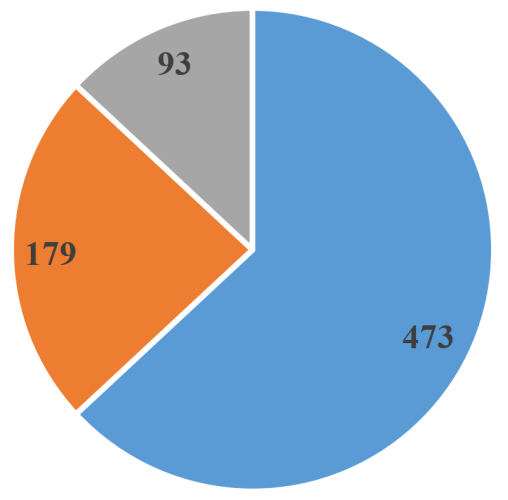

$$
\begin{aligned}
& \text { - Lisans - Yüksek Lisans - Doktora } \\
& \text { Şekil 1. Kamu/Siyaset/UAi Bölümlerindeki İnsan Hakları Derslerinin }
\end{aligned}
$$

\subsubsection{Lisans Dersleri}

Şekil 1'de görüldüğü üzere, siyaset/kamu/UAİ programlarında verilen toplam 745 dersin 473 tanesi lisans seviyesindedir. Temel ve alt insan hakları derslerinin sayıca en fazla yer aldığı üniversite 15 ders ile Dokuz Eylül Üniversitesidir. Dokuz Eylül Üniversitesini, 12 ders ile Çanakkale Üniversitesi ve 10'ar ders ile Adnan Menderes Üniversitesi, Bartın Üniversitesi ve Giresun Üniversitesi takip eder.

Lisans seviyesindeki toplam 473 dersin 322'si seçmeli, 135'i ise zorunlu derstir. Bir diğer deyişle, lisans seviyesindeki derslerin \% 68'i seçmeli ders kategorisinde yer almakta- dır. 16 ders hakkında zorunlu mu seçmeli mi olduklarına ilişkin bilgiye erişilememiştir. Zorunlu dersler ise toplam 63 ayrı üniversitede verilmektedir. Bu üniversitelerin yalnızca yedisi vakıf üniversitesi iken, geri kalan 56 tanesi devlet üniversitesidir. Bir diğer deyişle, lisans seviyesinde verilen zorunlu insan hakları derslerinin ağırlıklı olarak devlet üniversitelerinde verildiği söylenebilir.

Öte yandan, zorunlu derslerin 92 tanesi alt insan hakları alanı dersiyken, sadece 43 tanesi temel insan hakları dersleridir. Kamu/siyaset/UAİ bölümlerindeki zorunlu dersler ağırlıklı olarak (\%68) alt insan hakları alanları dersleridir. ${ }^{13}$ Üstelik bu sonuçların lisans programlarına ilişkin olduğu da unutulmamalıdır zira yüksek lisans veya doktora gibi uzmanlaşmanın daha fazla olduğu programlarda, bu tür alan derslerinin zorunlu olarak sunulması daha fazla beklenebilir.

Lisans derslerinin zorunlu/seçmeli olarak ayrılması sırasında ilginç bir tespit ile daha karşılaşılmıştır. Bu şekilde bir ayrıma gidildiğinde, tüm programlarında insan hakları alanına ait toplam 10 ders sunan Giresun Üniversitesinde verilen tüm derslerin zorunlu olduğu görülmüştür. Bu derslerden sadece bir tanesi -Demokrasi ve İnsan Hakları dersi- temel ders olarak kodlanmıştır. Giresun Üniversitesinde lisans seviyesinde kamu/siyaset/uluslararası ilişkiler programlarında verilen dokuz zorunlu ders ise, insan haklarının alt alanlarına ilişkin derslerdir. Bunların arasında üç çevre dersi, beş kent dersi ve bir göç dersi yer almaktadır. Tablo 2 Giresun Üniversitesindeki zorunlu derslerin alanlara göre dağılımını gösterir.

Tablo 2. Giresun Üniversitesindeki Zorunlu Derslerin Alanlara Göre Dağılımı

\begin{tabular}{|l|l|}
\hline Ders adı & Alan \\
\hline Çevre Sorunları ve Politikaları & Çevre \\
\hline Çevre ve Siyaset & Çevre \\
\hline Uluslararası Çevre Politikaları & Çevre \\
\hline Kent Ekonomisi & Kent \\
\hline Kentleşme Politikaları & Kent \\
\hline Kent Sosyolojisi & Kent \\
\hline Kentsel Dönüşüm & Kent \\
\hline Küreselleşme ve Kent & Kent \\
\hline Uluslararası Göç ve Nüfus Hareketleri & Göç \\
\hline
\end{tabular}

Giresun Üniversitesini, beşer ders ile Ankara Üniversitesi, Dokuz Eylül Üniversitesi ve Gazi Üniversitesi izlemektedir. Yukarı da da ele alındığı gibi, Türkiye'nin en büyük, en eski ve en saygın üniversiteleri arasında yer alan İstanbul Üniversitesi, Ortadoğu Teknik Üniversitesi ve Marmara Üniversitesinde ise kamu/siyaset/UAİ lisans programlarında zorunlu insan hakları dersleri sayıca oldukça azdır. İstanbul Üniversitesinde sadece Human Rights (İnsan Hakları) isminde bir ders bulunurken, Marmara Üniversitesinde ise Çevre Politikası ve Politiques de l'environnement (Çevre Politikaları) dersleri dışında zorunlu olarak

\footnotetext{
${ }^{13}$ Bu sonuç hukuk fakülteleriyle karşılaştırıldığında ilginç bir durum ortaya çıkar. Hukuk fakültelerinde verilen toplam 53 zorunlu dersin tamamı temel insan hakları alanı dersleridir. Bu sonuç zorunlu insan hakları dersleri olan hukuk fakültelerinde bu derslerin spesifik hak alanlarına yönelik olmadığını ortaya koyar (Kalem ve Akbaş, 2018).
} 
verilen başka derse rastlanmamıștır. ODTÜ'de ise kamu/ siyaset/UAİ lisans programlarında insan hakları alanında zorunlu derse rastlanmamıştır.

Dersler zorunlu/seçmeli ayrımının yanı sıra, bir de alanlarına göre kodlanmış ve bu çerçevede de 473 lisans dersinin 153'ünün temel insan hakları dersi olduğu görülmüștür. Temel insan hakları dersi olarak kodlananların içinde 43 ders zorunlu ders olarak müfredatta yer almakta iken, 103 ders ise seçmeli olarak sunulmaktadır. Geri kalan yedi derse ilişkin yeterli bilgiye ulaşılamamıştır. Öte yandan, kamu/siyaset/UAİ lisans programlarında verilen bu 43 zorunlu dersin yedi tanesi hariç geri kalan hepsi devlet üniversitelerinde verilmektedir. Süleyman Demirel Üniversitesi ve Trakya Üniversitesi birden fazla zorunlu temel insan hakları dersi sunan üniversitelerdir. Tablo 3 bu derslerin isimlerini ve üniversitelere göre dağılımını gösterir.

Tablo 3. Kamu/Siyaset/UAi Bölümlerindeki Zorunlu Temel Insan Hakları Dersleri (Lisans)

\begin{tabular}{|c|c|c|}
\hline Üniversite & Ders & $\mathrm{D} / \mathrm{V}$ \\
\hline Abant & İnsan Hakları & $\mathrm{D}$ \\
\hline Adıyaman & İnsan Hakları Hukuku & $\mathrm{D}$ \\
\hline Afyon & İnsan Hakları & $\mathrm{D}$ \\
\hline Ahi Evran & Temel Hak ve Hürriyetler & $\mathrm{D}$ \\
\hline Ahi Evran & Uluslararası İnsan Hakları & $\mathrm{D}$ \\
\hline Aksaray & Demokrasi ve İnsan Hakları & $\mathrm{D}$ \\
\hline $\begin{array}{l}\text { Altınbaş Kemer- } \\
\text { burgaz }\end{array}$ & Uluslararası Örgütler & V \\
\hline Anadolu & İnsan Hakları ve Demokratikleşme Süreci & $\mathrm{D}$ \\
\hline Anadolu & İnsan Hakları ve Kamu Özgürlükleri & $\mathrm{D}$ \\
\hline Ankara & $\begin{array}{l}\text { İnsan Haklarının Uluslararası Alanda } \\
\text { Korunması }\end{array}$ & $\mathrm{D}$ \\
\hline Ankara & Temel Haklar ve Özgürlükler & $\mathrm{D}$ \\
\hline Avrasya & İnsan Hakları Hukuku & V \\
\hline Bitlis Eren & Uluslararası İnsan Hakları & D \\
\hline Cumhuriyet & Temel Haklar ve Özgürlükler & $\mathrm{D}$ \\
\hline Çanakkale & İnsan Hakları ve Demokrasi & $\mathrm{D}$ \\
\hline Çankırı & Uluslararası İnsan Hakları & $\mathrm{D}$ \\
\hline Doğuş & $\begin{array}{l}\text { Human Rights and Human Security } \\
\text { Regimes }\end{array}$ & V \\
\hline Dumlupınar & İnsan Hakları & $\mathrm{D}$ \\
\hline Gazi & Uluslararası Alanda İnsan Hakları & $\mathrm{D}$ \\
\hline Giresun & Demokrasi ve İnsan Hakları & $\mathrm{D}$ \\
\hline Haliç & Uluslararası Örgütler & V \\
\hline Harran & İnsan Hakları Hukuku & $\mathrm{D}$ \\
\hline İstanbul & Human Rights & $\mathrm{D}$ \\
\hline İstinye & İnsan Hakları & V \\
\hline $\begin{array}{l}\text { Kahramanmaraş } \\
\text { Sütçü İmam }\end{array}$ & İnsan Hakları & $\mathrm{D}$ \\
\hline Karabük & İnsan Hakları & $\mathrm{D}$ \\
\hline Karadeniz Teknik & İnsan Hakları Hukuku & $\mathrm{D}$ \\
\hline Kastamonu & İnsan Hakları & $\mathrm{D}$ \\
\hline Kocaeli & Human Rights Law & $\mathrm{D}$ \\
\hline Munzur & İnsan Hakları Hukuku & $\mathrm{D}$ \\
\hline Muş Alparslan & İnsan Hakları & $\mathrm{D}$ \\
\hline Mustafa Kemal & İnsan Hakları & \\
\hline $\begin{array}{l}\text { Niğde Ömer Halis } \\
\text { Demir }\end{array}$ & İnsan Hakları Hukuku & $\mathrm{D}$ \\
\hline Nişantaşı & İnsan Hakları ve Hukuku & V \\
\hline Ordu & Hak ve Özgürlükler & D \\
\hline
\end{tabular}

\begin{tabular}{|l|l|l|}
\hline Üniversite & Ders & D/V \\
\hline $\begin{array}{l}\text { Recep Tayyip } \\
\text { Erdoğan }\end{array}$ & Sivil Toplum, Demokrasi ve İnsan Hakları & D \\
\hline Selçuk & İnsan Hakları & D \\
\hline Süleyman Demirel & $\begin{array}{l}\text { İnsan Haklarının Uluslararası Alanda } \\
\text { Korunması }\end{array}$ & D \\
\hline Süleyman Demirel & İnsan Hakları & D \\
\hline Trakya & İnsan Hakları & D \\
\hline Trakya & Uluslararası Boyutlarıyla İnsan Hakları & D \\
\hline Uludağ & Uluslararası İnsan Hakları & D \\
\hline Yeditepe & İnsan Hakları Hukuku & V \\
\hline
\end{tabular}

Sonuç olarak, lisans seviyesinde verilen temel insan hakları derslerinin sadece \%28'i zorunludur. Bir diğer ifadeyle, kamu/siyaset/UAİ bölümlerindeki zorunlu dersler ağırlıklı olarak alt insan hakları dersleridir (Kalem ve Akbaş, 2018). Şu noktada, alt insan hakları alanlarına ait derslere daha detaylı bakmakta fayda vardır. Lisans derslerinin 320 tanesinin alt insan hakları alanlarına ait dersler olduğu görülmektedir. Bu alanlar kamu/siyaset/UAİ bölümlerindeki dersler üzerinden altı başlıkta toplanmıştır ve aşağıda Şekil 2'de görüldüğü gibi dağılmaktadır.

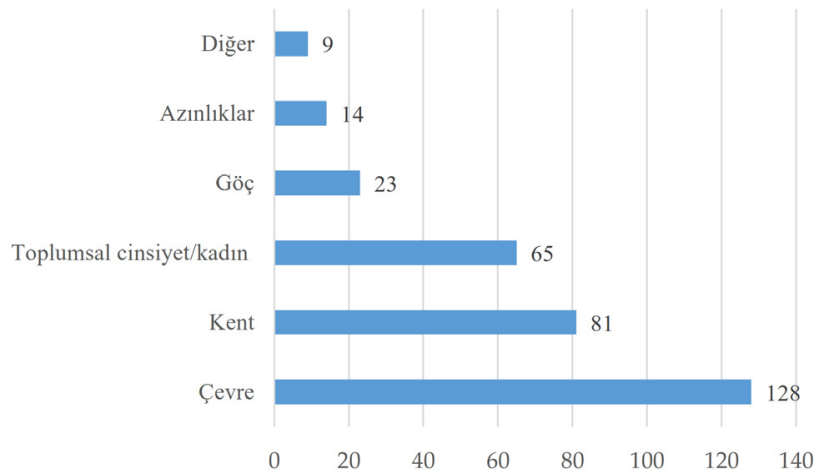

Şekil 2. Kamu/Siyaset/UAi Bölümlerindeki Alt İnsan Hakları Derslerinin Alanlara Göre Dağılımı (Lisans)

Görüldüğü gibi, kamu/siyaset/UAİ bölümlerinde lisans düzeyinde alt insan hakları alanı olarak en fazla çevre ve kent kategorilerine rastlanmaktadır. Şu noktada, yukarıda temel insan hakları dersleri için yapıldığı gibi, lisans seviyesinde verilen alt insan hakları derslerinin zorunlu/ seçmeli ayrımına da bakmak yerinde olacaktır. Toplam 320 alt insan hakları alanı dersinin 219 tanesinin seçmeli, 92 tanesinin ise zorunlu olduğu görülmektedir. Geri kalan dokuz ders hakkkında yeterli bilgiye erişilememiştir. Şekil 3 ve Şekil 4'te lisans seviyesindeki zorunlu ve seçmeli derslerin alanlara göre dağılımı gösterilmiștir.

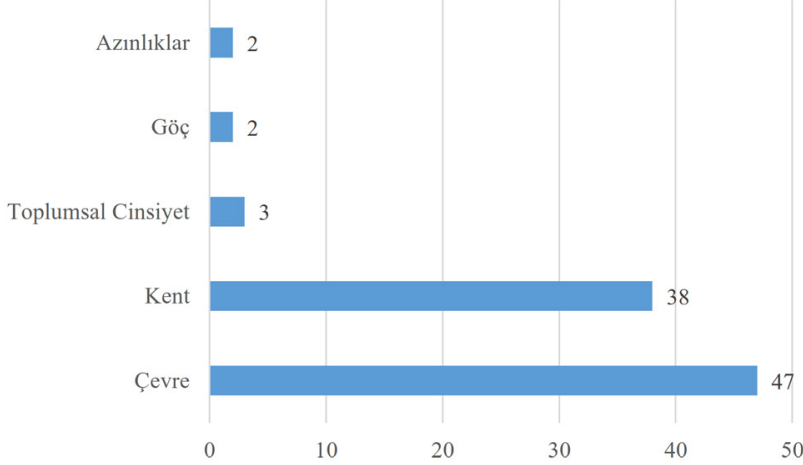


Şekil 3. Kamu/Siyaset/UAi Bölümlerindeki Zorunlu Derslerin Alanlara Göre Dağılımı (Lisans)

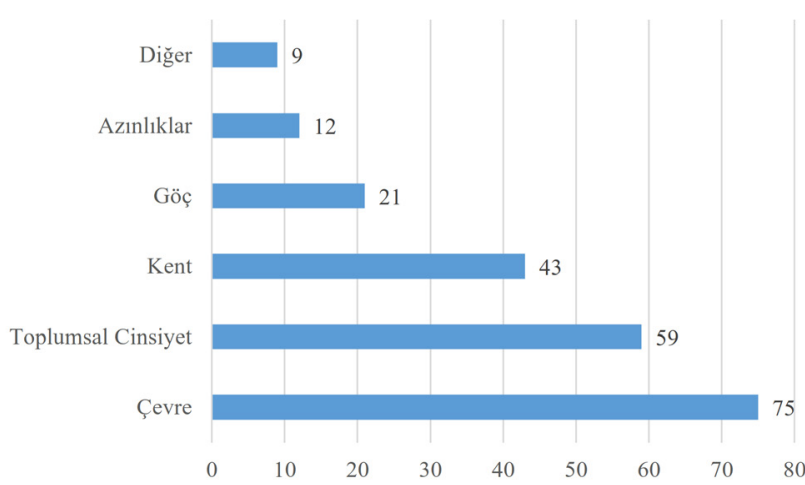

Şekil 4. Kamu/Siyaset/UAi Bölümlerindeki Seçmeli Derslerin Alanlara Göre Dağılımı (Lisans)

Son olarak, alt insan hakları alanları olarak kodlanan derslere biraz daha yakından bakalım.

\subsubsection{1 Çevre}

Öncelikle, yukarıda da ifade edildiği gibi çevre konulu dersler hem genel olarak alt insan hakları dersleri arasında sayıca en fazla olan derslerdir, hem de bu derslerin zorunlu ders olarak da en fazla sunulan dersler oldukları görülmektedir. Kamu/siyaset/UAİ lisans programlarında hem zorunlu hem seçmeli olarak sunulan toplam 128 çevre konulu dersin \%36's zorunludur. Bu durum hukuk fakültelerindekinden farklıdır zira hukuk lisans programlarında da çevre hukuku ve benzeri dersler yoğun olmakla birlikte, bu derslerin ekseriyetle seçimlik dersler olduğu görülmüştür. Üstelik kentleşme ve benzeri başlıklı derslerin de hukuk fakültelerine ilişkin analizde çevre başlığı altında değerlendirildiğini de unutmamak gerekir (Kalem ve Akbaș, 2018). Öte yandan, kamu/siyaset/UAİ bölümlerinde verilen çevre konulu derslere baktığımız zaman, hukuk fakültelerinde tespit edilen çevre hukuku ağırlığının da geçerli olmadığını görmek mümkündür (Kalem ve Akbaş, 2018). Aşağıdaki başlıkların da ortaya koyacağı üzere, bu bölümlerdeki çevre konulu derslerin insan hakları alanıyla ilişkili olma olasılığı daha yüksektir.

$$
\begin{aligned}
& \text { - Çevre bilimi } \\
& \text { - Çevre eğitimi ve politikaları } \\
& \text { - Çevre ekonomisi } \\
& \text { - Çevre etiği } \\
& \text { - Çevre hukuku } \\
& \text { - Çevre politikaları } \\
& \text { - Çevre yönetimi } \\
& \text { - Küreselleşme ve ekoloji } \\
& \text { - Çevre ve siyaset } \\
& \text { - Uluslararası çevre politikaları }
\end{aligned}
$$

\subsubsection{Kent}

Alt insan hakları alanı olarak en fazla ders sunulan ikinci alan kent kategorisidir. Kent konusundaki dersler sayısal olarak lisans seviyesinde çevre derslerinden sonra en sık rastlanılan dersler olmuştur. Toplam 81 dersin içinde 43 tanesi seçmeli iken, 38 tanesi ise zorunlu olarak verilen derslerdir. Görüleceği gibi, çevre konusunda olduğu gibi kent çalışmalarında da zorunlu ders oranı yüksek sayılabilir (\%47). Kent ve çevre konuları birbirlerine yakın konular oldukları için, bazı derslerin her iki alanda da sayılabileceği görülmüş, bu gibi durumlarda dersin sadece bir alana dâhil edilmesine dikkat edilmiștir. Kent alanındaki dersler de şöyledir:

- Güncel kent sorunları

- Kent sosyolojisi

- Kent ve çevre etiği

- Kent kuramları

- Kent ve bölge planlama

- Kentleşme politikaları

- Kent ve çevre sorunları

- Kentsel hizmetler ve konut politikası

- Kentsel siyaset

- Kentsel yoksulluk ve sosyal dişlanma

\subsubsection{Toplumsal Cinsiyet/Kadın}

Alt insan hakları derslerinin 65 tanesi toplumsal cinsiyet alanına ait derslerdir. Çevre ve kent konulu derslerin tersine, toplumsal cinsiyet dersleri ağırlıklı olarak seçmeli derslerdir. Bir diğer ifadeyle, toplumsal cinsiyet ile ilgili derslerin kamu/siyaset/UAİ bölümlerinde lisans seviyesinde öğrencilerin ilgi alanları doğrultusunda seçebilecekleri dersler olarak yapılandırıldıklarını, toplumsal cinsiyet perspektifinin öğrencilerin öğrenim hayatlarında mutlak edinmeleri gereken bir yaklaşım olarak görülmediğini öne sürmek mümkündür. Lisans seviyesindeki toplam 65 dersin içinde sadece üç ders farklı üniversitelerin kamu/ siyaset/uluslararası ilişkiler bölümlerinde zorunlu olarak açılmaktadır. Bu dersler, Dokuz Eylül Üniversitesindeki Cinsiyet Eşitliği dersi, Batman Üniversitesinde verilen Toplumsal Cinsiyet dersi ve Gaziosmanpaşa Üniversitesindeki Toplumsal Cinsiyet ve Politika dersleridir. Batman Üniversitesindeki ders hakkında başka bilgiye erişilememiștir; fakat Dokuz Eylül Üniversitesi ve Gaziosmanpaşa Üniversitesindeki derslerin insan hakları perspektifiyle verilen toplumsal cinsiyet dersleri oldukları görülmüştür.

$\mathrm{Bu}$ derslerin arasında aşağıdaki başlıklar veya benzerleri yer almaktadır.

- Toplumsal cinsiyet eşitliği

- Toplumsal cinsiyet ve siyaset

- Aile ve sosyal cinsiyet sosyolojisi

- Cinsiyet politikası

- Kadın çalışmalarına giriş

- Kadin ve siyaset

- Türk modernleșmesinin cinsiyeti

- Türkiye'de kadın hareketinin gelişimi

- Toplumsal cinsiyet politikaları

- Toplumsal cinsiyet ve kültür 


\subsubsection{Göc}

Göç üzerine dersler de alt insan hakları alanında sayılabilecek derslerdir. Taranan 473 lisans dersinin içinde toplam 23 tane göç konulu derse rastlanmış, bunların 21 tanesi seçmeli ders iken, sadece 2 tanesinin zorunlu olarak verilen dersler oldukları görülmüştür. Bu zorunlu dersler Adnan Menderes Üniversitesindeki Uluslararası İlişkiler ve Göç dersi ile Giresun Üniversitesinde verilen Uluslararası Göç ve Nüfus Hareketleri dersleridir. Giresun Üniversitesindeki dersin öğretim elemanı hakkında bilgiye erişilememiş olmakla birlikte, ders tanıtımındaki bilgiler dersin bu alana ait bir ders olduğunu düşündürtmektedir. $\mathrm{Bu}$ dersler dışında dâhil edilen dersler ise şöyledir.

- Nüfus ve göç hareketleri

- Göç politikası

- Uluslararası ilişkilerde göç

- Uluslararası hukukta göç ve mülteciler

- Uluslararası göç siyaseti

- Uluslararası göç

\subsubsection{Azınlıklar}

Azınlıklar başlığı ise sayıca az olmakla birlikte, alt insan hakları alanı olarak değerlendirilebilecek bir başka alan olarak sayılmıştır. Azınlıklar konusunda toplam 14 derse rastlanmış ve bunların 12 tanesinin seçmeli ders olduğu görülmüştür. Zorunlu olarak verilen iki dersten biri Ankara Üniversitesindeki Milliyetçilik ve Azınlıklar dersi, diğeri ise Karadeniz Teknik Üniversitesinde verilen aynı isimdeki derstir. Her iki ders de tanımları itibarıyla insan hakları ile ilişkilendirilebilir durmaktadır. Bu başlık altına giren diğer derslere örnek verecek olursak:

- Azınlık hakları

- Azınlık hakları ve milliyetçilik

- Türkiye'de azınlıklar

- Ortadoğu'da milliyetçilik ve azınlıklar

- Uluslararası politikada azınlık

\subsubsection{Diğer}

Dokuz ders ile diğer başlığı altında kodlanmıştır. Bu kategorideki milliyetçilik konulu dersler azınlık hakları dersleriyle bir arada da düşünülebilir. Ancak bu dersler ağırlıklı olarak teorik dersler oldukları için ayrı olarak kategorize edilmişlerdir. Hukuk fakültelerinde karşımıza çıkan sağlık hukuku, bilim hukuku, çocuk hakları dersleri, kamu/ siyaset/UAİ lisans programlarında sayıca o kadar azdır ki ancak diğer kategorisine dâhil edilebilmişlerdir (Kalem ve Akbaş, 2018).

\subsubsection{Yüksek Lisans Dersleri}

Yukarıda Şekil 1'de görüldüğü üzere, kamu/siyaset/UAİ bölümlerinde verilen toplam 745 dersin, 179 tanesi yüksek lisans seviyesindedir. Bu derslerin verildiği 66 üniversite arasında temel ve alt insan hakları derslerinin sayıca en fazla yer aldığı üniversite 12 ders ile Çanakkale Üniversitesidir. Çanakkale Üniversitesinde yüksek lisans prog- ramlarında özellikle çevre ve kent konulu dersler ağırlıktadır. Bu üniversiteyi 11 ders ile Dokuz Eylül Üniversitesi ve 10 ders ile Bülent Ecevit Üniversitesi takip eder. Lisans programlarında yüksek sayıda derse sahip olduğu görülen Giresun Üniversitesinde ise yüksek lisans programları bulunmamaktadır.

Yüksek lisans programlarında verilen bu derslerin neredeyse tamamı seçmelidir. Seçmeli mi zorunlu mu olduğu anlaşılamayan üç ders kapsam dışı bırakıldığında, geriye kalan dersler arasında zorunlu verilen ders sayısı sadece 10 'dur. Bu oran lisans seviyesindeki orana (\%68) klyasla oldukça azdır. Bu durumun elbette yüksek lisans programlarının daha spesifik konulara odaklanmasıyla yakından ilgili olması muhtemeldir. Ancak burada söz konusu olan programların daha ziyade siyaset/kamu/UAİ yüksek lisans programı oldukları da unutulmamalıdır.

Zorunlu derslerin dağılımına baktığımızda, yarısının temel insan hakları dersleri, geri kalan beş tanesinin de iki toplumsal cinsiyet, iki kent ve bir çevre dersi olmak üzere alt insan hakları dersleri oldukları görülür. Burada ilginç bir bulgu Cumhuriyet Üniversitesine ilişkindir. Bu üniversitede kamu yönetimi yüksek lisans programındaki dört ders de zorunlu derslerdir. Bir diğer deyişle, toplam 10 zorunlu dersin dördü Cumhuriyet Üniversitesinde verilmektedir. Zorunlu derslerin tamamı devlet üniversitelerindeki yüksek lisans programlarında verilmektedir. Bu derslerin üniversitelere göre dağılımı Tablo 4'te gösterilmiştir.

Tablo 4. Kamu/Siyaset/UAi Bölümlerindeki Zorunlu Temel ve Alt Insan Hakları Dersleri (YL)

\begin{tabular}{|l|l|l|}
\hline Üniversite & Ders adı & Ders türü \\
\hline Ahi Evran & Kentsel ve Çevresel Sorunlar & Alt \\
\hline Ankara & Türk Modernleşmesinin Cinsiyeti & Alt \\
\hline Bilecik Şeyh Edebali & Politik Ekoloji & Alt \\
\hline Cumhuriyet & İnsan Hakları Hukuku & Temel \\
\hline Cumhuriyet & $\begin{array}{l}\text { Globalleşmenin Kentleşme Üzerine } \\
\text { Etkileri }\end{array}$ & Alt \\
\hline Cumhuriyet & $\begin{array}{l}\text { İnsan Haklarının Korunması ve Koruma } \\
\text { Mekanizmaları }\end{array}$ & Temel \\
\hline Cumhuriyet & Medya, Toplumsal Cinsiyet ve Siyaset & Alt \\
\hline Dumlupınar & İnsan Hakları & Temel \\
\hline Kocaeli & $\begin{array}{l}\text { Türkiye ve Avrupa İnsan Hakları Mah- } \\
\text { kemesi }\end{array}$ & Temel \\
\hline Necmettin Erbakan & $\begin{array}{l}\text { İnsan Hakları ve Uluslararası Koruma } \\
\text { Mekanizmaları }\end{array}$ & Temel \\
\hline
\end{tabular}

Dersler zorunlu/seçmeli ayrımının yanı sıra, bir de alanlarına göre kodlanmış ve bu çerçevede de 179 yüksek lisans dersinin 71 tanesinin temel insan hakları dersi olduğu görülmüştür. Yukarıda da belirtildiği gibi, temel insan hakları derslerinin arasında sadece beş ders zorunludur ve hepsi de devlet üniversitelerindeki programlarda verilmektedir.

Üç tane seçmeli mi zorunlu mu olduğu belli olmayan ders kapsam dışı bırakıldığında, yüksek lisans programlarındaki 108 ders ise alt insan hakları alanlarına ait derslerdir. Bu dersler lisans derslerindeki başlıklar altında kodlanmıştır. Şekil 5 derslerin alanlara göre dağı- 
lımını gösterir.

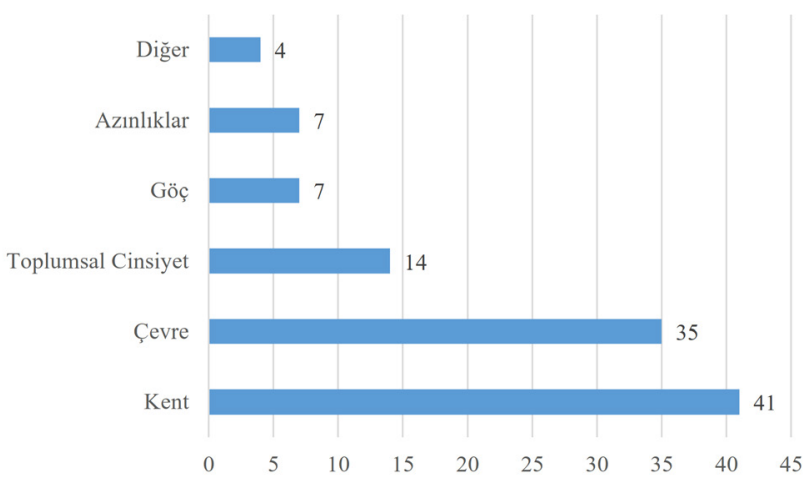

Şekil 5. Kamu/Siyaset/UAi Bölümlerindeki Alt Insan Hakları Derslerinin Alanlara Göre Dağılımı (YL)

Görüldüğü gibi, kamu/siyaset/UAİ bölümlerinde yüksek lisans düzeyinde alt insan hakları alanı olarak en fazla kent ve çevre kategorilerine rastlanmaktadır. Bu durum lisans programlarındaki durum ile tutarlıdır (Kalem ve Akbaş, 2018). Şu noktada, yüksek lisans seviyesinde verilen alt insan hakları derslerinin zorunlu/seçmeli ayrımına da bakmak yerinde olacaktır. Toplam 108 alt insan hakları alanı dersinin sadece beş tanesi zorunludur. Diğer derslerin biri hakkında açıklayıcı bilgiye ulaşılamamış, geriye kalan 103 dersin tamamının seçmeli dersler olduğu tespit edilmiştir. Zorunlu derslerin sayısı çok az olduğu için burada bu derslerin alanlara göre dağılımını ortaya koymaya gerek yoktur.

Yukarıda da bahsedildiği gibi, alt insan hakları alanında verilen zorunlu derslerin ikisi toplumsal cinsiyet, ikisi kent ve bir tanesi de çevre konularında verilen derslerdir. Alt insan hakları alanında verilen derslere biraz daha detaylı bakacak olursak:

\subsubsection{Kent}

Yüksek lisans seviyesinde sayıca en fazla olan dersler kent konusunda verilen derslerdir. $\mathrm{Bu}$ alandaki 41 dersin iki tanesi dışında geri kalanları seçmeli derslerdir. Ahi Evran Üniversitesindeki Kentsel ve Çevresel Sorunlar isimli ders ile Cumhuriyet Üniversitesinde verilen Globalleşmenin Kentleşme Üzerindeki Etkileri isimli ders bu alandaki zorunlu derslerdir. Her iki ders hakkında da yeterli bilgi edinilememesi nedeniyle bu derslerin gerçek anlamda insan hakları dersi olup olmadıkları hakkında birşey söylemek mümkün değildir.

\subsubsection{2 Çevre}

Lisans programlarına kıyasla, kent alanındaki derslerin gerisinde kalsa da, çevre konusundaki dersler yüksek lisans programlarında da en fazla verilen dersler arasındadır. Yüksek lisansta sunulan toplam 35 dersin sadece biri zorunludur ve bu ders Bilecik Şeyh Edebali üniversitesinde verilen Politik Ekoloji isimli derstir.

\subsubsection{Toplumsal Cinsiyet}

Yüksek lisans programlarında toplam 14 tane toplumsal cinsiyet dersine rastlanmıştır. Bunların iki tanesi zorunlu, geri kalanı seçmelidir. Cumhuriyet Üniversitesindeki
Medya, Toplumsal Cinsiyet ve Siyaset dersi ile Ankara Üniversitesinde açılan Türk Modernleşmesinin Cinsiyeti dersi yüksek lisans programlarında verilen zorunlu derslerdir. Burada da gene öğretim elemanlarının kim oldukları bilinmekle birlikte, dersler hakkında daha fazla bilgiye erişilemediği için, toplumsal cinsiyet konusunu ne şekilde işlediklerini ve dolayısıyla insan hakları alanıyla ne derece ilgili olduklarını tespit etmek güçtür.

Diğer taraftan, Türkiye üniversitelerinde 1990lı yılların başından itibaren kadın çalışmaları anabilim dalları kurulduğu, bunların da fakülteler içinde değil sosyal bilimler enstitüleri içinde yapılandırıldığı ve bu şekilde yüksek lisans ve doktora programları açabildikleri de bilinmektedir (Can, 2006). Proje kapsaminda toplanan veri sadece kamu/siyaset/UAİ bölümleriyle ilişkili programlara odaklandığı için, enstitüler bünyesinde çalışan bu anabilim dalları dışarıda bırakılmıştır. Bu nedenle bu programlarda verilen dersler veri tabanı içinde yer almamaktadır. Ancak özellikle de toplumsal cinsiyet alanında Türkiye akademisinin mevcut durumunu ortaya koymaya çalışan daha geniş bir çalışmada, bu yüksek lisans ve doktora programlarının da incelenmesi şarttır. ${ }^{14}$

\subsubsection{Göc}

$\mathrm{Bu}$ alandaki ders sayısı yedi ile sınırlıdır. Tamamı seçmeli olan bu dersler devlet üniversitelerinde verilmektedir ve genelde mülteciler başlığını da içermektedir.

\subsubsection{Azınlıklar}

Yüksek lisans programlarında azınlıklar konusunda ilişkin dersler de sayıca oldukça azdır. Bu alana ait toplam yedi dersin tamamı seçmelidir.

\subsubsection{Diğer}

Yüksek lisans programlarında bu başlık altında kodlanan toplam dört ders bulunmaktadır. Tamamı seçmeli olan bu derslerin başlıkları şöyledir:

- Etnik Sorunlar ve Milliyetçilik

- Medya-İktidar ve Demokrasi

- 21.Yy.da Teori ve Uygulamada Kendi Kaderini Tayin Hakkı, Terörizm ve Uluslararası Hukuk

- Hukuk Devletinin Güncel Sorunları

\subsubsection{Doktora Dersleri}

Toplam 93 ders ise doktora seviyesindedir. Bunların sadece iki tanesi zorunlu ders iken 91 ders ise seçmeli olarak verilmektedir. Zorunlu derslerin her ikisi de toplumsal cinsiyet konulu derslerdir. Bunlardan ilki Marmara Üniversitesindeki Toplumsal Cinsiyet başlıklı derstir. Diğeri ise Ankara Üniversitesinde verilen ve yüksek lisans programında da yer alan Türk Modernleşmesinin Cinsiyeti isimli derstir. Burada da görüleceği üzere, yüksek lisans dersleri ile doktora dersleri zaman zaman ortak açılabilmektedir. Ancak ortak ders havuzu durumu bulunmadığı için bu programlar ayrı analiz edilmiştir.

$\mathrm{Bu}$ derslerin 30 tanesi temel insan hakları dersleridir ve

${ }^{14} \mathrm{Bu}$ anabilim dallarında yapılan çalışmalara dair bilgi için bkz. (Sarıtaş, 2013). 
bunların hiçbiri zorunlu değildir. Alt insan hakları dersleri ise toplamda 63 tanedir. Bu derslerin iki tanesi yukarıda da belirtildiği gibi zorunludur. Hakkında bilgiye ulaşılamayan üç ders dışarıda bırakıldığında, alt insan hakları derslerinin 58 tanesinin seçmeli olduğu söylenebilir. Alt insan hakları derslerinin konularına göre dağılımı Şekil 6'da gösterilmiștir.

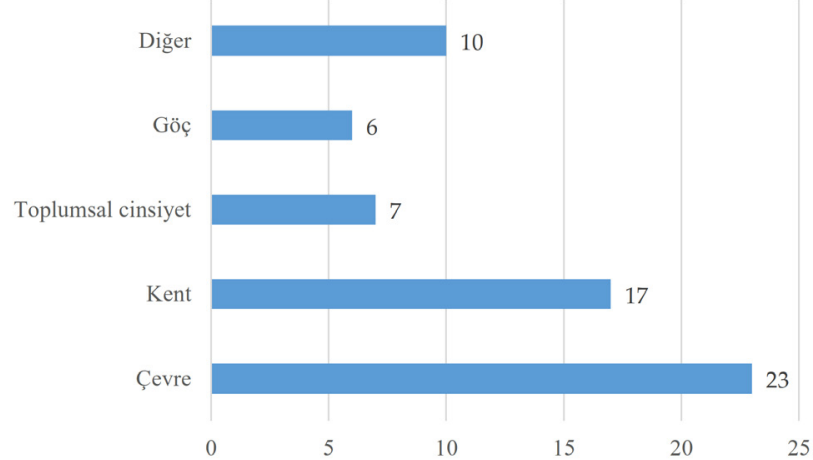

Şekil 6. Kamu/Siyaset/UAi Bölümlerindeki Alt İnsan Hakları Derslerinin Alanlara Göre Dağılımı (Doktora)

Tıpkı lisans ve yüksek lisansta olduğu gibi, burada da çevre ve kent konularında verilen derslerin ağırlıkta olduğu görülmektedir. Alt insan hakları alanında verilen derslere biraz daha detaylı bakacak olursak:

\subsubsection{1 Çevre}

Doktora programlarında yer alan çevre konusundaki dersler toplam 23 tanedir ve bunların tamamı seçmeli derslerdir. Dokuz Eylül Üniversitesi dört ders ve Akdeniz Üniversitesi üç ders ile bu alanda en fazla dersin verildiği üniversitelerdir. Dokuz Eylül'de Uluslararası Çevre Hukuku, AB'de Çevre Yönetimi ve Uluslararası Politik Etkileşim, Bütünleşik Çevre Yönetimi ve Çevre Standartları ile Çevresel Etki Projeleri (ÇED) ve Stratejisi dersleri bulunmaktadır. Sonuncu ders dışında ilk bakışta yüksek lisans ve doktora dersleri arasında başka örtüşme görünmemektedir. Ancak Uluslararası Çevre Hukuku dersi dışındaki derslerin hepsinin aynı öğretim üyesi tarafından veriliyor olması bu derslerin birbirlerinden ne derece farklılaştıları konusunda soru işareti uyandırmaktadır. Öte yandan, Akdeniz Üniversitesinin Kamu Yönetimi Doktora programında, Küresel Çevre ve Su Politikaları, Uluslararası Çevre Politikaları ile Çevre Sorunları ve Çevre Yönetimi dersleri mevcuttur. Her biri başka bir öğretim üyesi tarafından verilen bu dersler yüksek lisans dersleriyle benzerlik gösterseler de aynı dersler değildir.

\subsubsection{Kent}

$\mathrm{Bu}$ alanda doktora seviyesinde verilen toplam 17 ders bulunmuştur ve bunların da tamamı seçmeli derslerdir. Abant Üniversitesi, Afyon Üniversitesi ve Aksaray Üniversitesi kent konusunda sundukları üçer ders ile bu alanda en fazla ders açan üniversitelerdir. Üstelik bu programlardaki dersler yüksek lisans programlarındakilerden farklıdır. Abant Üniversitesinde zaten yüksek lisans seviyesinde kent konulu ders bulunmamaktadır. Afyon Üniversitesinde verilen Güncel Kentsel Sorunlar ve Politika- ları, Kent Kuramları ve Kentsel Haklar ve Türkiye dersleri ile Aksaray Üniversitesinde verilen Kent Güvenliği, Kent Kuramları ve Kuramciları ile Kentleșmede Temel Meseleler dersleri yüksek lisans programlarında yer almayan derslerdir. Ancak bu derslerin hiçbirinin içeriğine ya da öğretim elemanına ilişkin bilgi bulunamadığı için, dersler hakkında daha fazla söz söylemek mümkün değildir.

\subsubsection{Toplumsal Cinsiyet}

Doktora programlarında yer alan yegâne iki zorunlu dersin toplumsal cinsiyet alanındaki dersler olması bu alana verilen önemi tek başına ortaya koymaktan uzaktır. Zira kamu/siyaset/UAI doktora programlarinda toplumsal cinsiyet alanında sadece yedi ders bulunması, bu alana yeterince önem verilmediğini ispatlar niteliktedir. Ayrıca bu dersler sadece devlet üniversitelerinde verilmektedir.

\subsubsection{Göc}

98 ders arasında göç konulu altı derse rastlanmıştır.

\subsubsection{Diğer}

Doktora programlarında diğer başlığı altında toplanan ders sayısı diğer programlara göre oldukça yüksektir. Toplam 14 seçmeli ders diğer başlığı altında toplanmıştır. Bu durum doktoa programlarında ders çeşitliliğine daha fazla önem verildiği izlenimi uyandırır. Her birinin konuyla ilgisi tek tek kontrol edilerek eklenen bu derslerin isimleri şöyledir:

- Barış Çalışmaları ve Çatışma Çözümleri

- Küresel İletişim ve Uluslararası İlişkiler

- Avrupa Birliği Entegrasyonu ve Demokrasi

- Güvenlik ve Sınır Așan Sorunlar

- Etnisite ve kimlik

- Yüksek Öğretimin Ekonomi-Politiği

- Eğitimin Siyasal ve Ekonomik Temelleri

- 21. yüzyılda Halkların Kendi Kendini Tayin Hakkı

- Dünya Azınlıkları

- AB'de Sosyal Hukuk

\subsection{Merkezler}

Çalışma kapsamında, hukuk fakültesi ve/veya kamu/ siyaset bölümlerinden birine sahip üniversitelerde bulunan insan hakları merkezleri de ayrıca incelenmiştir. Insan hakları alanında faaliyet gösterdiği düşünülen toplam 162 merkez tespit edilmiştir. Bu merkezler 19 tanesi vakıf üniversitesi olmak üzere toplam 84 üniversitede bulunmaktadır. Toplam 162 merkezin 34 tanesi bu 19 vakıf üniversitesinin çatısı altında yer almaktadır. Bunlar da ağırlıklı olarak -14 tanesi- İstanbul'da bulunan üniversitelerdir. Son 20 yılda çok sayıda vakıf üniversitesi kurulmuş olmasına rağmen, bu üniversitelerin Türkiye'deki araştırma olanaklarına ve akademik faaliyetlere katkılarının beklendiği kadar yoğun olmadığına dikkat çekilebilir. Türkiye'de akademik araştırma ve faaliyetler hâlâ ağırlıklı olarak devlet üniversiteleri bünyesinde gerçekleştirilmektedir. İnsan hakları alanında çalışan merkezlere sahip olan vakıf üniversitelerinin listesi aşağıdaki tabloda gösteril- 
miştir.

Tablo 5. Merkez Bulunan Vakıf Üniversiteleri

\begin{tabular}{|l|c|c|}
\hline \multicolumn{1}{|c|}{ Üniversite } & Merkez sayısı & Şehir \\
\hline Altınbaş & 1 & İstanbul \\
\hline Atılım & 1 & Ankara \\
\hline Avrasya & 2 & Trabzon \\
\hline Bahçeşehir & 1 & İstanbul \\
\hline Başkent & 2 & Ankara \\
\hline Beykent & 2 & İstanbul \\
\hline Çağ & 1 & Mersin \\
\hline İstanbul Aydın & 2 & İstanbul \\
\hline İstanbul Bilgi & 5 & İstanbul \\
\hline İstanbul Gedik & 2 & İstanbul \\
\hline İstanbul Kültür & 1 & İstanbul \\
\hline İstanbul Ticaret & 2 & İstanbul \\
\hline İzmir Ekonomi & 2 & İzmir \\
\hline Kadir Has & 1 & Istanbul \\
\hline Koç & 3 & İstanbul \\
\hline Maltepe & 2 & İstanbul \\
\hline Sabancı & 1 & İstanbul \\
\hline Üsküdar & 2 & İstanbul \\
\hline Yeni Yüzyıl & 1 & İstanbul \\
\hline
\end{tabular}

Öte yandan, bu merkezlerin 10 tanesi temel insan hakları alanında çalışmalar yapan merkezler iken, 152 tanesi ise alt insan hakları alanında faaliyet göstermektedir. Faaliyet gösterme ifadesi de ayrıca açıklamayı gerekli kılar. İsminden insan hakları alanı ile ilgili olduğu düşünülen bu merkezlerin 72 tanesi hakkında (\%45) yeterli bilgiye erişilememiştir. Bir diğer deyişle, bu merkezlerin müdürleri dışında -ki bazen bu bilgi bile eksiktir- projeleri, eğitimleri, konferansları/toplantıları veya yayınları hakkında hiçbir bilgiye erişilememiştir. Dolayısıyla, bu merkezlerin tam olarak ne tür faaliyetleri olduğu, hatta faaliyette olup olmadıkları bile anlaşılamamıştır. Bu sıkıntı bazen merkezin web sayfası olmamasından, bazen o sayfaya erişilememesinden, çoğunlukla da sayfada merkezin faaliyetlerine ilişkin hiçbir bilgi bulunmamasından kaynaklanmaktadır.

Bilgi eksikliği bulunan merkezlerin, tarihlerine ilişkin bilginin mevcut olduğu durumlarda ise ağırlıklı olarak son yıllarda kurulan merkezler olduğu görülmüştür. Ancak bu durumun istisnaları da vardır. Özellikle çevre konusunda çalışan ve 1980'li ve 1990'lı yıllarda kurulan bazı merkezlere ilişkin de hiçbir bilgiye rastlanmamıștır. Örneğin Cumhuriyet Üniversitesi Çevre Sorunları Uygulama ve Araştırma Merkezi (1987), Gaziantep Üniversitesi Çevre Araştırma Merkezi (1990) ve Dumlupınar Üniversitesi Çevre Sorunları Araştırma ve Uygulama Merkezi (1991) bu tür bilgi eksikliği bulunan eski merkezlerdir.

Tüm üniversiteler arasında en fazla merkezi bünyesinde barındıran üniversiteler ise ise Boğaziçi Üniversitesi ve İstanbul Bilgi Üniversitesidir. Boğaziçi Üniversitesinde ikisi çevre alanında olmak üzere, toplam beş merkez bulunmaktadır. Bunların arasında en eskisi olan (2002) İnsani Gelişme Uygulama ve Araştırma Merkezinin faaliyetleri hakkında bilgiye erişilememiş olmasından dolayı bu birimin ne derece faal olduğu bilinmemektedir. Ancak diğer dört merkez -Barış Eğitimi Uygulama ve Araştırma Mer- kezi (2007), Sürdürülebilir Kalkınma ve Temiz Üretim Uygulama ve Araştırma Merkezi (2007), Eğitim Politikaları Uygulama ve Araştırma Merkezi (2012) ve İklim Değişikliği ve Politikaları Uygulama ve Araştırma Merkezi (2014)- hakkında edinilen bilgiler bu birimlerin faaliyette olduklarını ortaya koyar. İstanbul Bilgi Üniversitesinde ise İnsan Hakları Hukuku Uygulama ve Araştırma Merkezi bu çalışma kapsamında temel insan hakları alanında çalışan merkez olarak kodlanmış olmakla birlikte esasen çalışma alanları alt konulardan göç, toplumsal cinsiyet, engellilik gibi konuları da kapsayan oldukça faal bir merkezdir. Bu iki üniversiteyi dörder merkez ile Hacettepe Üniversitesi ile Bülent Ecevit Üniversitesi takip eder. Her iki üniversitedeki birimlerin de faaliyette olduğu görülmüştür. Oysa Karadeniz Teknik Üniversitesinde de dört merkez olduğu bilinmekle birlikte bunların içinde sadece kadın hakları merkezi hakkında az bir bilgiye erişilmiş, geri kalan üç merkezin faaliyetleri hakkında ise bilgi edinilememiştir. Öte yandan Van Yüzüncü Yıl Üniversitesi ise ilginç bir örnek ortaya koyar. Bu üniversitede farklı alanlarda çalışmak üzere kurulmuş yedi tane merkez olduğu görülmesine rağmen bu merkezlere ilişkin kuruluş tarihleri de dâhil olmak üzere herhangi bir bilgiye erişim mümkün olmamıştır.

İstanbul Üniversitesi, Marmara Üniversitesi, Ankara Üniversitesi ve Koç Üniversitesinde ise üçer tane merkez olduğu görülmüş, bunların neredeyse tamamının faal olduğu tespit edilmiştir. Ancak Ankara Üniversitesi Siyasal Bilgiler Fakültesi İnsan Hakları Merkezi'nin yapısının ve içeriğinin değiștirilerek Rektörlüğe bağlanmasını takiben 2017 yılında yerine kurulan İnsan Hakları Uygulama ve Araştırma Merkezi hakkında kuruluş tarihi dışında bilgiye erişilemediği için bu merkezin henüz faaliyete geçip geçmediği bilinmemektedir. Aynı şekilde Türkiye akademisinin en köklü yüksek öğrenim kurumlarından birisi olan ODTÜ'de ise insan hakları alanında çalışan yegâne merkez İnsan Hakları ve Güvenliği Uluslararası Araştırma ve Uygulama Merkezidir; ancak bu birimin ne kendine ait bir web sayfası bulunmaktadır ne de hakkında başka bir bilgiye erişilebilmiştir.

Öte yandan, yukarıda da belirtildiği üzere, çatısı altında insan hakları alanında çalışan merkez barındıran vakıf üniversitesi sayısı ise toplam 19'dur ve bu üniversitelerin arasında en fazla sayıda faal şekilde çalışan merkeze sahip üniversite ise İstanbul Bilgi Üniversitesidir. Bu üniversitedeki İnsan Hakları Hukuku Uygulama ve Araştırma Merkezi, Çocuk Çalışmaları Birimi ve Sosyoloji ve Eğitim Çalışmaları Uygulama ve Araştırma Merkezi, Göç Çalışmaları Uygulama ve Araştırma Merkezi ile Çevre, Enerji ve Sürdürülebilirlik Uygulama ve Araştırma Merkezinin gerek yürütülen projeler, düzenlenen toplantılar ve eğitimler gerekse yapılan yayınlar bağlamında hayli faal birimler oldukları görülmüştür.

\subsubsection{Temel insan hakları alanında çalıșan merkezler}

Yukarıda da belirtildiği gibi temel insan hakları alanında 
çalıștı̆̆ı izlenimi uyandıran toplam 10 merkeze rastlanmıștır. ${ }^{15}$ Ancak bu merkezlerin yarısı hakkında yeterli bilgi yoktur. İlk olarak, esasen 1978 yllında kurulmuş olan Ankara Üniversitesi Siyasal Bilgiler Fakültesi İnsan Hakları Merkezinin kapatılmasını takiben 2017 yılında yerine kurulan İnsan Hakları Uygulama ve Araştırma Merkezi hakkında kuruluş tarihi ve müdürü dışında hiçbir bilgiye erişilememiştir. Uzun ylllar siyasi ve hukuki alanda bilgi üretimine katkıda bulunan eski merkezin tüm ișlerine erişimin de ortadan kalkmış olması kuşkusuz akademik hafıza açısından da oldukça sıkıntı vericidir. Aynı zamanda, Galatasaray Üniversitesi Ceza Bilimleri ve Kriminoloji ve İnsan Hakları Araştırma Merkezi hakkında da müdürün ismi dışında herhangi bir bilgi mevcut değildir. Gazi Üniversitesi İnsan Hakları Uygulama ve Araştırma Merkezi (2017), İstanbul Gedik Üniversitesi İnsan Hakları Uygulama ve Araştırma Merkezi (2016) ile ODTÜ İnsan Hakları ve Güvenliği Uluslararası Araştırma ve Uygulama Merkezine ait de bilgiye erişim mümkün olmamıștır.

Dolayısıyla, toplam 10 merkezin içinde esasen faal olduğu görülen beş insan hakları merkezi bulunmaktadır. Bunlar Tablo 6'da gösterilmiştir.

Tablo 6. Faal Temel Insan Hakları Merkezleri

\begin{tabular}{|c|c|c|}
\hline Üniversite & Merkez & $\begin{array}{l}\text { Kuruluş } \\
\text { Yılı }\end{array}$ \\
\hline Hacettepe & $\begin{array}{l}\text { İnsan Hakları ve Felsefesi Uygulama ve Araştırma } \\
\text { Merkezi }\end{array}$ & 1997 \\
\hline İstanbul & Insan Hakları Hukuku Uygulama ve Araştırma Merkezi & 1997 \\
\hline $\begin{array}{l}\text { İstanbul } \\
\text { Bilgi }\end{array}$ & Insan Hakları Hukuku Uygulama ve Araştırma Merkezi & 2000 \\
\hline Maltepe & Insan Hakları Merkezi & 2005 \\
\hline Selçuk & Insan Hakları Araştırma ve Uygulama Merkezi & BY \\
\hline
\end{tabular}

Temel insan hakları alanında kurulan merkezlerin olduğu üniversitelerde, alt insan hakları alanında faaliyet gösteren merkez var mı diye baktığımızda ise, faal olduğu tespit edilen merkezlerin bulunduğu üniversitelerde aynı zamanda alt insan hakları merkezleri olduğu da görülmüştür. Hakkında bilgi olmayan beş üniversite arasında ise sadece İstanbul Gedik Üniversitesinde aynı zamanda Kadın ve Toplumsal Cinsiyet Uygulama ve Araştırma Merkezinin de olduğu görülmüsstür. Ancak bu Merkez hakkında da bilgi bulunmamaktadır.

\subsubsection{Alt insan hakları alanlarında çalıșan merkezler}

Yukarıda da belirtildiği gibi, merkezler ağırlıklı olarak alt insan hakları alanlarında faaliyet göstermek amacıyla kurulmuşlardır. Temel insan hakları alanına dâhil edilen merkezler dışında toplam 152 merkezin isimlerinde insan haklarının spesifik alanlarında faaliyet göstermeyi amaçladıkları anlaşılmaktadır. Bu alanların sayısal dağılımı Tablo 7'de gösterilmiştir. Toplam 67 merkez hakkında ise bilgi edinilememiştir.

\subsubsection{Kadın/Toplumsal Cinsiyet}

Türkiye'de kadın çalışmaları alanında ilk merkez 1989 yllında İstanbul Üniversitesi bünyesinde kurulan Kadın Sorunları Araştırma ve Uygulama Merkezidir (KAUM).

${ }^{15}$ Bu kodlama da merkezlerin isimlerine göre yapılmıştır. Bu merkezlerin alt insan hakları alanlarında da faaliyetleri olabileceği unutulmamalıdır.
Tablo 7. Alt Insan Hakları Alanlarındaki Merkezler

\begin{tabular}{|c|c|c|}
\hline Alt alan & Toplam merkez sayısı & $\begin{array}{c}\text { Bilgi olmayan } \\
\text { merkez sayısı }\end{array}$ \\
\hline Kadın/Toplumsal Cinsiyet & 67 & 24 \\
\hline Çevre/Kent & 36 & 18 \\
\hline Çocuk & 17 & 10 \\
\hline Göç & 12 & 6 \\
\hline Engelliler & 7 & 5 \\
\hline Romanlar & 2 & 1 \\
\hline Diğer & 11 & 3 \\
\hline
\end{tabular}

Bu merkezi 1994 yılında Çukurova Üniversitesinde kurulan Kadın Sorunları Araştırma ve Uygulama Merkezi (KADAUM) takip eder. Bunları takiben 1997 yılında Gaziantep Üniversitesi ve Mersin Üniversitesinde kurulan kadın araştırmaları merkezleri ile birlikte 2000li yıllara kadar Türkiye akademisinde kadın hakları alanında faaliyet gösteren sayısı dördü geçmez. Şekil 7'de de görüleceği gibi bu durum 2000li ylllarda değişmekte, özellikle 2009, 2012, 2015 ve 2016 senelerinde kadın merkezlerinde hızlı bir artışa rastlanmaktadır (Savaş, Ertan ve Yol, 2018).

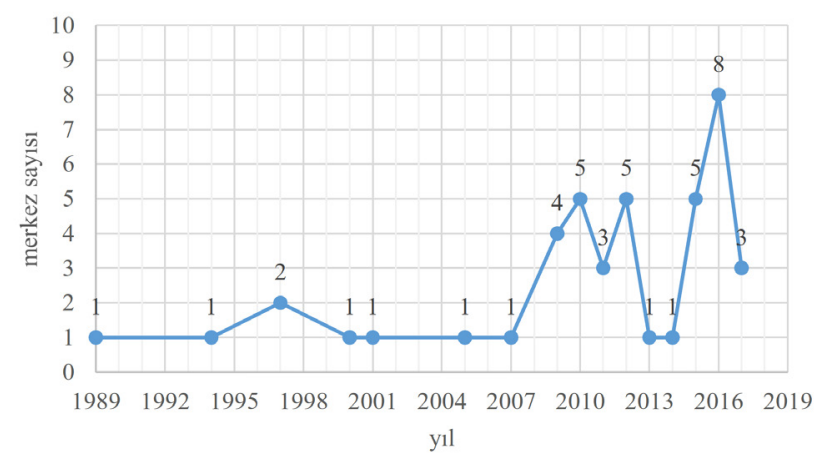

Şekil 7. Kadın Merkezlerinin Kuruluş Tarihleri

Tablo 8. Yıllara Göre Merkez Sayısındaki Artışın Dağılımı

\begin{tabular}{|c|c|c|}
\hline Yıl & Merkez sayısı & Üniversiteler ve kuruluş yılları \\
\hline 2009 & 4 & $\begin{array}{l}\text { Çanakkale (1992) } \\
\text { Dokuz Eylül (1982) } \\
\text { Kırıkkale (1992) } \\
\text { Eskişehir Osmangazi (1993) }\end{array}$ \\
\hline 2012 & 5 & $\begin{array}{l}\text { Atatürk (1957) } \\
\text { Çankaya (1997) } \\
\text { Giresun (2006) } \\
\text { Kadir Has (1997) } \\
\text { Namık Kemal (2006) }\end{array}$ \\
\hline 2015 & 5 & $\begin{array}{l}\text { Bülent Ecevit (1992) } \\
\text { Niğde Ömer Halisdemir (1992) } \\
\text { Sabancı (1999) } \\
\text { Sinop (2007) } \\
\text { Trakya (1982) }\end{array}$ \\
\hline 2016 & 8 & $\begin{array}{l}\text { Bayburt (2008) } \\
\text { Beykent (1997) } \\
\text { Erzincan (1976) } \\
\text { Fırat (1975) } \\
\text { Gazi }(1926) \\
\text { Hitit (2006) } \\
\text { Karabük (2007) } \\
\text { Marmara (1883/1982) }\end{array}$ \\
\hline
\end{tabular}

$\mathrm{Bu}$ artış 1990ların ortalarından itibaren üniversite say1sindaki -özellikle de vakıf üniversitelerinin kurulmasıyla gerçekleșen- hızlı artış ile birlikte düşünülebilir. Ancak, özelllikle artışın çok olduğu dört yıla bakıldığında, bu açıklamanın yetersiz kaldığı görülmektedir. Așağıda Tab- 
lo 8'de de görülebileceği gibi, bu dört yılda kurulan toplam 22 merkezin sadece 3 tanesi vakıf üniversitelerindedir.

Bu çalışmada da fakültelerdeki durumun aksine, toplumsal cinsiyet ve kadın konularının araştırma ve uygulama merkezlerinin çalışma alanları içerisinde ağırlıklı olarak yer aldığı görülmüştür. Bu alanda çalıştığı tespit edilen toplam 67 merkezin içinde ağırlıklı olarak (50 merkez) kadın sorunları/kadın çalışmaları/kadın araștırmaları isimli merkezler yer almaktadır. Az sayıda merkezin (7) başlığında ise kadın/aile/çocuk bir arada yer almaktadır. Bunların içinde dört adet kadın ve aile çalışmaları merkezi, bir tane Kadın-Çocuk Sağlığı ve Aile Planlaması Araştırma ve Uygulama Merkezi, bir tane aile araştırmaları merkezi ile bir adet de Kadın, Aile ve Toplum Hizmetleri Uygulama ve Araştırma Merkezi isimli birim yer almaktadır. Diğer taraftan üç merkez kadın ve toplum konusuna odaklanmakta, bir tane de Kadın ve Genç Girişimcileri Destekleme Eğitim, Uygulama ve Araştırma Merkezi bulunmaktadir. Son olarak, isimlerinde hem toplumsal cinsiyete hem kadına yer veren merkez sayısı ise yedidir. Bu merkezlerin 14 tanesi vakıf üniversitelerinde, geri kalan 53 tanesi ise devlet üniversitelerindedir. Ancak Boğaziçi ve ODTÜ gibi Türkiye akademisinin saygın iki devlet üniversitesinde kadın ve/veya toplumsal cinsiyet alanında faaliyet gösteren merkez bulunmaması da dikkat çekicidir.

Öte yandan, yukarıda belirtildiği gibi toplam 67 merkezin içinde hakkında yeteri bilgiye erişilemeyen 24 tane merkez ise kadın ve toplumsal cinsiyet alanında çalıştıkları düşünülen merkezlerdir. Şu durumda incelenen toplam 162 merkez içinde 67 tane kadın merkezi olduğu göz önünde bulundurulunca, bu merkezlerin yaklaşık \%36'sı hakkında yeterli bilgiye sahip olmadığımız sonucu çıkmaktadır. Bu 24 merkezin kuruluş tarihleri de genelde eksiktir ancak mevcut olan tarihlere bakıldığında genelde 2010 sonrası kurulan merkezler olduklarını söylemek mümkündür. Bu durum da kadın ve toplumsal cinsiyet alanında çalışma yapmak üzere kurulan bu yeni merkezlerin ne kadar faal olduklarını sorgulamayı gerektirir ki bu sorgulama da esasen bu alandaki merkezlerin genelde ne kadar verimli ve üretken olduklarına ilişkin bir şüpheyle de yakından ilgilidir. Nitekim Savaş, Ertan ve Yol (2018), Türkiye'de kadın araştırmaları merkezlerinin birçoğunun faal olmadığını ve yaptıkları çalışmaların genellikle konferans, seminer ve sosyal etkinlikler ile sinırlı olduğunu ortaya koymaktadır.

Üniversitelerdeki kadın merkezleri artış göstermeye başladıkları 2000li yıllardan itibaren akademik çalışmaların da konusu olmaya başlamıştır (Çilingiroğlu, 2001; Özvarış ve Akın, 2003; Balcı, 2016). Ancak yukarıda sözü geçen Savaş vd. (2018) çalışması dışında bu konuyu merkezler hakkında genel bilgi derlemekten öteye taşıyan bir akademik çalışmaya da rastlanmamıştır.

\subsubsection{2 Çevre}

Çevre ve kent konularında çalıştıkları düşünülen toplam 36 merkez tespit edilmiştir ancak bunların da gene yarısı hakkında bilgiye ulaşılamamıştır. Bu merkezlerin sadece altı tanesi vakıf üniversitelerinde, geri kalan 30 tanesi ise devlet üniversitelerindedir.

Bunların içinde en eski merkez ise 1978 yllında Atatürk Üniversitesinde kurulan Çevre Sorunları Araştırma Merkezidir. Çevre konusunda çalışan merkezlerin genel olarak en erken kurulan merkezler oldukları görülmektedir. Nitekim çalışmaya dâhil edilen merkezlerin tamamı mevcut bilgiler ışığında kuruluş tarihlerine göre en eskiden en yeniye göre sıralandığında, ilk 10 merkezin dokuzunun çevre alanında çalışan merkezler olduğu görülebilir.

Tablo 9. Kuruluş Tarihleri Açısından En Eski Merkezler

\begin{tabular}{|l|l|c|}
\hline \multicolumn{1}{|c|}{ Üniversite } & \multicolumn{1}{c|}{ Merkez } & $\begin{array}{c}\text { Kuruluş } \\
\text { yılı }\end{array}$ \\
\hline Atatürk & Çevre Sorunları Araştırma Merkezi & 1978 \\
\hline Cumhuriyet & Çevre Sorunları Uygulama ve Araştırma Merkezi & 1987 \\
\hline Marmara & Çevre Sorunları Uygulama ve Araştırma Merkezi & 1987 \\
\hline İstanbul & Kadın Sorunları Araştırma ve Uygulama Merkezi & 1989 \\
\hline Gaziantep & Çevre Araştırma Merkezi & 1990 \\
\hline Ankara & Çevre Sorunları Araştırma ve Uygulama Merkezi & 1990 \\
\hline Ege & Çevre Sorunları Uygulama ve Araştırma Merkezi & 1990 \\
\hline Çukurova & Çevre Sorunları Araştırma ve Uygulama Merkezi & 1990 \\
\hline Anadolu & Çevre Sorunları Uygulama ve Araştırma Merkezi & 1991 \\
\hline Dumlupınar & Çevre Sorunları Araştırma ve Uygulama Merkezi & 1991 \\
\hline Dokuz Eylül & Çevre Araştırma ve Uygulama Merkezi & 1991 \\
\hline Akdeniz & Çevre Sorunları Araştırma ve Uygulama Merkezi & 1991 \\
\hline Erciyes & Çevre Sorunları ve Temiz Üretim Uygulama ve & 1991 \\
\hline
\end{tabular}

Gene kuruluş tarihleri açısından, çevre konusunda faaliyet gösteren merkezlerin ağırlıklı olarak 1990lı yılların başında kurulduğu, 1995-2005 yılları arasında bu konuda çalışan yeni merkez kurulmadığı, 2005 yılından sonra 1990lı yıllara kıyasla az da olsa bir artış görüldüğü söylenebilir. Bu değerlendirme, kuruluş tarihleri hakkında bilgiye erişilemeyen 12 merkez dışarıda bırakılınca geriye kalan 24 merkez üzerinden yapılmıştır.

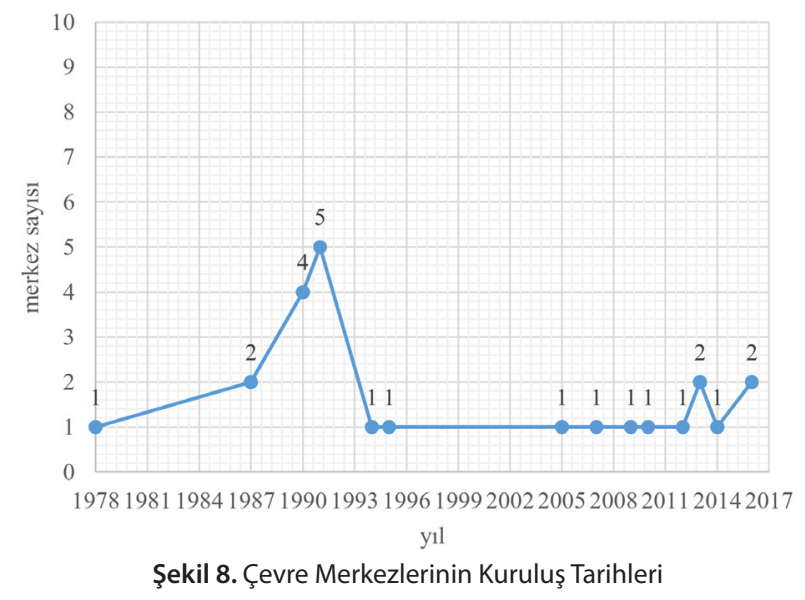

\subsubsection{3 Çocuk}

Elde edilen bilgiler Türkiye'de çocuk alanında çalışan 17 tane merkez olduğunu ortaya koymaktadır. İstanbul Bilgi Üniversitesi ve Maltepe Üniversitesi dışında, çocuk alanında faaliyet gösteren merkezlerin tamamı devlet üniversitelerindedir. $\mathrm{Bu}$ merkezlerin sadece yedi tanesinin kuruluş tarihlerine erişim mümkün olmuştur. $\mathrm{Bu}$ tarihlere göre, en eski merkez 2002 yılında Hacette- 
pe Üniversitesinde kurulan Çocuk Hakları Uygulama ve Araștırma Merkezidir. Gene mevcut bilgiler ıșığında, en yeni merkezin ise 2017 yllında Eskișehir Osmangazi Üniversitesinde kurulan Çocuk Koruma Uygulama ve Araştırma Merkezi olduğu görülmektedir. Öte yandan, kuruluş tarihlerine erişilemeyen 10 merkez hakkında başka herhangi bir bilgiye de erişilemediğinden, tam olarak bu merkezlerin ne tür faaliyetlerde bulunduğunu söylemek mümkün değildir.

\subsubsection{Göç}

Türkiye üniversitelerinde göç araştırmaları alanında çalışan toplam 12 merkez tespit edilmiștir. Ancak bunların altı tanesi hakkında neredeyse hiçbir bilgiye erişilemediği için bu alanda yapılan çalışmalara ilişkin fazla söz söylemek de mümkün değildir. Bu merkezler arasında 2004 yılında kurulan Koç Üniversitesi Göç Araştırmaları Uygulama ve Araştırma Merkezi (MiReKoc), 2005 yllında İstanbul Bilgi Üniversitesinde kurulan Göç Çalışmaları Uygulama ve Araştırma Merkezi, Hacettepe Üniversitesi Göç ve Siyaset Araştırmaları Merkezi (HUGO) ile 2014 yılında kurulan Bahçeşehir Üniversitesi Göç ve Kent Çalışmaları Merkezi (BAUMUS) oldukça faal oldukları izlenimi verirken, Bülent Ecevit Üniversitesi Göç Araştırma ve Uygulama Merkezi (2012) ile Ankara Yıldırım Beyazıt Üniversitesi Göç Politikaları Uygulama ve Araştırma Merkezi (2015) hakkında az da olsa bilgi edinilmiş olmakla birlikte bu birimlerin güncel olarak neler yaptıklarını tespit etmek mümkün olmamıştır.

\subsubsection{Engelliler}

Türkiye'deki akademik çalışmalar içerisinde engellilik konusunun bir insan hakları alanı olarak araștırma yapılmaya, üzerinde proje yürütmeye değer bir konu olarak görüldüğünü söylemek mümkün değildir. Fakültelerde gördüğümüz tablo merkezlerde de gözlenmiştir. Taramanın yapıldığı dönemde Dicle Üniversitesinde verilen iki engelli hakları dersi dışında siyaset bilimi bölümlerinde bu konuyla ilgili açılan başka derse rastlanmamıştır. Merkezlerde de toplam yedi merkezin isimleri itibarıla bu alanda çalıştıkları görülmüş ancak bunların sadece iki tanesinin aktif olarak çalıştığı tespit edilmiștir. İstanbul Üniversitesindeki merkez dışında, bir tek Yeni Yüzyıl Üniversitesindeki merkez yeni kurulmuş olmasına rağmen faal bir görüntü çizmektedir.

Tablo 10. Engelliler Alanındaki Merkezler

\begin{tabular}{|l|l|l|}
\hline Üniversite & Merkez & $\begin{array}{l}\text { Kuruluş } \\
\text { yılı }\end{array}$ \\
\hline Dicle & Engelliler Uygulama ve Araştırma Merkezi & 2010 \\
\hline Ege & $\begin{array}{l}\text { Engelli Çocuklar Rehab. ve Eğt. Parkı Araştırma ve } \\
\text { Uygulama Merkezi }\end{array}$ & BY \\
\hline Fırat & Engelliler Araştırma ve Uygulama Merkezi & BY \\
\hline İstanbul & Engelliler Uygulama ve Araştırma Merkezi & 2014 \\
\hline Karabük & Engelliler Eğitimi Uygulama ve Araştırma Merkezi & 2016 \\
\hline $\begin{array}{l}\text { Van Yüzün- } \\
\text { cü Yıl }\end{array}$ & Engelliler Araştırma ve Uygulama Merkezi & BY \\
\hline Yeni Yüzyıl & $\begin{array}{l}\text { Yuvam (Engelsiz Üniversite Uygulama ve Araştırma } \\
\text { Merkezi) }\end{array}$ & 2017 \\
\hline
\end{tabular}

\subsubsection{Romanlar}

Bu başlık esasen diğer başlığı altına da dâhil edilebilecek bir alan olmakla birlikte, çok spesifik bir ayrımcilık alanı olduğu için ve birden fazla merkeze rastlandığı için ayrı olarak kodlanmıştır. Bu alandaki iki merkezden biri 2011 yilında Adnan Menderes Üniversitesinde kurulan Romanlar Uygulama ve Araştırma Merkezidir. Ancak kalabalık bir kadroyla çalıştığı görülen bu merkezin faaliyetlerine ilişkin bir bilgiye erişilememiștir. Öte yandan 2015 senesinde Bülent Ecevit Üniversitesinde kurulan Roman Kültürü Uygulama ve Araştırma Merkezi ise gene fazla veri olmamakla birlikte, 2015 senesinde Romanları Anlamak Çalıștayı ve Batı Karadeniz Romanlar Derneği Roman Çalıştayı isimli iki çalıştay düzenlendiği bilgisine erişildiği için görece daha faal bir merkez izlenimi uyandırmıștır.

\subsubsection{Diğer}

Toplam 162 merkezin içinde 11 merkezin faaliyet alanları belirlenen temel insan hakları veya alt insan hakları alanları altında kodlanamadığı için diğer başlı̆̆ı altına dâhil edilmiştir. Diğer kategorisinde en fazla merkezi bulunan üniversite Boğaziçi Üniversitesidir. Bu merkezler Tablo 11'de gösterilmiştir.

\begin{tabular}{|c|c|c|}
\hline Üniversite & Merkez & $\begin{array}{c}\text { Kuruluş } \\
\text { yılı }\end{array}$ \\
\hline Galatasaray & Toplumsal Araştırmalar Merkezi & 2004 \\
\hline Erzincan & $\begin{array}{l}\text { Bilişim Teknolojisi ve Bilişim Hukuku Uygulama } \\
\text { ve Araştırma Merkezi }\end{array}$ & 2010 \\
\hline $\begin{array}{l}\text { Karadeniz } \\
\text { Teknik }\end{array}$ & Hasta Hakları Uygulama Araştırma Merkezi & BY \\
\hline Üsküdar & $\begin{array}{l}\text { Şiddet ve Suçla Mücadele Uygulama ve Araştır- } \\
\text { ma Merkezi }\end{array}$ & BY \\
\hline Boğaziçi & İnsani Gelişme Uygulama ve Araştırma Merkezi & 2002 \\
\hline Boğaziçi & Barış Eğitimi Uygulama ve Araştırma Merkezi & 2007 \\
\hline Boğaziçi & $\begin{array}{l}\text { Eğitim Politikaları Uygulama ve Araştırma } \\
\text { Merkezi }\end{array}$ & 2012 \\
\hline $\begin{array}{l}\text { İstanbul } \\
\text { Aydın }\end{array}$ & Global Barış ve Demokrasi Merkezi & BY \\
\hline İstanbul Bilgi & $\begin{array}{l}\text { Sosyoloji ve Eğitim Çalışmaları Uygulama ve } \\
\text { Araştırma Merkezi }\end{array}$ & BY \\
\hline Koç & $\begin{array}{l}\text { Küresel Kamu Hukuku Çalışmaları Uygulama ve } \\
\text { Araştırma Merkezi }\end{array}$ & BY \\
\hline Sakarya & $\begin{array}{l}\text { Anayasa Çalışmaları Uygulama ve Araştırma } \\
\text { Merkezi }\end{array}$ & 2016 \\
\hline
\end{tabular}

\section{SONUÇ VE ÖNERILER}

Bu çalışmanın parçası olduğu araştırma projesi, Türkiye'de yükseköğretimde insan hakları alanında üretilen ve paylaşlan bilginin niceliğine ilişkin veri toplayarak, bu alandaki mevcut akademik duruma ilişkin bazı tespitler ortaya koyacak bir temel araştırma (baseline study) olarak tasarlanmıştır. Bu bağlamda, proje çerçevesinde elde edilen bilgiler üzerinden Türkiye genelinde hukuk fakültelerinde ve kamu/siyaset/UAİ bölümlerinde lisans ve lisansüstü/ doktora seviyelerinde verilen temel insan hakları ve alt insan hakları derslerine ve insan hakları alanında çalışan araştırma merkezlerine ilişkin kapsamlı bir veri tabanı oluşturulmuştur. Araştırma bilgiye erişim ve özellikle de 
niteliksel bilgi derlemesi bakımından sınırlılıkları olan bir çalışma olmakla birlikte, Türkiye akademisinin insan hakları alanında nerede durduğuna ilişkin genel bir resim çizebilmiştir ve bu haliyle bu alanda çalışmak isteyen araştırmacılara temel veriler sunması itibarıyla önemli bir çalışma olma niteliğini taşımaktadır. Şu noktada, çalışmanın ortaya koyduğu bazı tespitler üzerinden insan hakları alanındaki tecrübelerin paylaşılması ve ihtiyaç tespiti yapılarak bu alanda çalışan bölümlerin, merkezlerin ve araştırmacıların kapasitelerinin güçlendirilmesi de ayrıca mümkün olacaktır.

Bu çerçevede, bu çalışmanın odağına aldığı kamu/siyaset/ UAİ bölümlerindeki duruma bakıldığında, bu programlarda insan hakları alanında üniversite başına ortalama üç ders düştüğü görülmektedir. Kamu/siyaset/UAİ bölümlerinin sayıca çokluğu göz önünde bulundurulduğunda bu sayı oldukça yetersiz kalmaktadır. Bu tabloda devlet üniversitelerinin vakıf üniversitelerine göre daha fazla ders sundukları, bunun da kapasiteleri ile doğru orantılı olduğu görülmektedir. Ancak bu üniversiteler arasında İstanbul Üniversitesi, Marmara Üniversitesi ve ODTÜ gibi Türkiye'nin en eski, akademik alanda en saygın ve kontenjanları da oldukça yüksek olan devlet üniversitelerinde insan hakları derslerinin sayıca oldukça düşük olduğu da görülmektedir.

$\mathrm{Bu}$ bölümlerde verilen derslerin programlar arası dağıl1mına bakıldığında ise, toplam derslerin yarısından fazlasının lisans seviyesinde olduğu ve bunların da ağırlıklı olarak (\%68) seçmeli dersler olduğu görülmektedir. Az sayıda olan zorunlu ders de çoğunlukla devlet üniversitelerinde verilmektedir ve bunlar da ağırlıklı olarak alt insan hakları alanlarına ilişkin derslerdir. Öte yandan, lisans düzeyinde alt insan hakları alanı olarak en fazla çevre ve kent alanlarında dersler olduğu ve bu alanlardaki derslerin de üçte birinin zorunlu dersler olduğu görülmüştür. Toplumsal cinsiyet dersleri ise, tüm alt alan derslerinin \%20sini oluşturmaktadır ve bu oranla çevre ve kent konulu derslere kıyasla sayıca oldukça azdır. Öte yandan, toplumsal cinsiyet dersleri ağırlıklı olarak seçmeli olarak açılan derslerdir (\%95). Lisans seviyesinde verilen çevre konulu derslerin yaklaşık \%36'sının, kent konulu derslerin ise yaklaşık \%47'sinin zorunlu dersler olduğu göz önünde bulundurulunca, kamu/siyaset/UAİ bölümlerinin öğrencilere toplumsal cinsiyet perspektifi kazandırmaktan uzak olduğu söylenebilir. $\mathrm{Bu}$ alandaki derslerin hem sayıca az olması hem de açılan derslerin ağırlıklı olarak seçmeli olması, toplumsal cinsiyet konusunun öğrencilerin ilgi alanları doğrultusunda veya ders programları elverdiği sürece bilgi edindikleri bir alan olduğunu ortaya koymaktadır. Sağlık hukuku, bilim hukuku, çocuk hakları derslerinin ise kamu/siyaset/UAİ lisans programlarında yok denecek kadar az olduğu ortaya çıkmıştır.

Kamu/siyaset/UAİ bölümlerindeki yüksek lisans ve doktora programlarına bakıldığı zaman ise, 179 dersin yüksek lisans seviyesinde olduğu ve bu derslerin verildiği 66 üniversite arasında temel ve alt insan hakları derslerinin sayıca en fazla yer aldığ kale Üniversitesi olduğu görülmüştür. Ayrıca bu derslerin ağırlıklı olarak seçmeli dersler olduğu ve 10 zorunlu dersin ise dört tanesinin Cumhuriyet Üniversitesinde verildiği de tespit edilmiştir. Bu 179 yüksek lisans dersinin \%40'1 temel insan hakları dersi, geri kalan \%60'ı ise alt insan hakları alanlarındaki derslerdir. Alt insan hakları alanı olarak da yüksek lisans seviyesinde de lisans seviyesinde olduğu gibi en fazla kent ve çevre kategorilerine rastlanmaktadır; toplumsal cinsiyet dersleri ise \%13'lük bir orana karşılık gelmektedir. Öte yandan, yüksek lisans programlarının doğaları itibarıyla öğrencileri çok daha özel alanlarda çalışmaya teşvik etmelerinden dolayı, bu programlardaki seçmeli ders oranı beklenileceği üzere zorunlu derslere kıyasla oldukça yüksektir. Nitekim kamu/siyaset/UAI yüksek lisans programlarında verilen toplam 179 dersin arasında zorunlu ders sayısı 10'dur. Ancak bu derslerin yarısını oluşturan alt insan hakları derslerinin üç tanesi çevre ve kent konulu dersler iken iki tanesinin ise toplumsal cinsiyet dersi olduğu görülmektedir. Öte yandan, kamu/siyaset/UAİ programlarındaki doktora derslerinin sayısı ise 93'tür ve ikisi hariç bunların hepsi seçmelidir. Zorunlu derslerin ikisi de toplumsal cinsiyet konulu derslerdir. Ancak bu alanın dersleri zorunlu olarak sunulsa da, doktora programlarında toplumsal cinsiyet derslerine genel olarak oldukça az rastlanmaktadır. Bu programlarda da ağırlık çevre ve kent derslerindedir.

Merkezlere bakıldığı zaman ise tespit edilen toplam 162 merkezin sadece 34 tanesinin vakıf üniversitelerinde kurulduğu ve bunların da 19 vakıf üniversitesine dağıldığı görülmüştür. Bir diğer deyişle, insan hakları alanında çalıştığı düşünülen merkezler ağırlıklı olarak devlet üniversitelerinde kurulmuştur. Toplam 162 merkezin on tanesi dışında hepsi alt insan hakları alanında çalışmaktadır ve bu alanlar arasında da en sık karşımıza çıkan alan toplumsal cinsiyet ve kadın alanıdır. Çevre konusunda çalışan merkezler ise ikinci sıradadır ve en eski merkezler de yine ağırlıklı olarak çevre konularında çalışan merkezlerdir. Bir diğer deyişle, kamu/siyaset/UAİ bölümlerindeki seçmeli dersler arasında toplumsal cinsiyet derslerine çevre ve kent konulu derslere göre çok daha az rastlanmakla birlikte, merkezler ağırlıklı olarak toplumsal cinsiyet alanında çalışmaktadır. Ancak, merkezlerle ilgili yeterince bilgiye erişilemediğinden, bu verinin eksikliği analiz konusunda dikkatli olmayı gerekli kılmaktadır.

Sonuç olarak, burada değerlendirildiği kadarıla ve biçimiyle mevcut veriler, kamu/siyaset/UAİ bölümlerinde insan hakları alanına yönelik akademik ilginin niceliğine ilişkin söz söyleme imkanı tanımaktadır. Ancak bu akademik ilginin mevcut akademik kapasite ile ilişkilendirilmesi, çalışmayı tespit çalışması olmaktan çıkarıp bu alanda yapılabilecek politikalara zemin oluşturabilecek bir çalışma haline getirecektir. Bu nedenle, ortaya çıkan tablonun ne tür bir akademik kapasiteye karşılık geldiğinin ve bu kapasitenin ne şekilde geliştirilebileceğinin 
de değerlendirilmesi yerinde olacaktır. Benzer șekilde, bu tarama çalışmasının başka bölümler üzerinden yürütülmesi de oldukça önemlidir. Örneğin, insan haklarının anlaşılması bu hakların korunabilmesinin ön koşulu olduğundan, felsefe öğrenimi bu alanda yadsınamayacak bir öneme sahiptir (Kuçuradi, 2018, s. 8). Bu nedenle, üniversitelerde yapılacak çalışmaların felsefe bölümlerini de kapsaması yerinde olacaktır. Benzer şekilde sosyoloji bölümleri de özellikle de alt insan hakları konulu dersler bakımından buradaki veriye önemli katkılar sağlayabilecek bölümlerdir. Benzer șekilde, yukarıda da bahsedildiği üzere sosyal bilimler enstitüleri altında kurulan ve 2019 itibarıyla sayısı 15 civarında olan kadın çalıșmaları anabilim dallarının da incelenmesi, toplumsal cinsiyet konusunun Türkiye akademisinde çalșsılma biçimine ilişkin çok daha detaylı bir tablo ortaya koyacaktır. Aynı zamanda, tıp, mimarlık ve eğitim fakültelerindeki duruma ilişkin benzer çalışmalar yapmak da yine bu başlangıç çalışmasının ortaya koyduğu tabloyu zenginleștirecektir.

Son olarak, kuşkusuz yükseköğretimde insan hakları alanının geliştirilmesine katkı sunma amacının tam olarak gerçekleşmesi bu çalışmanın niteliksel olarak derinleştirilmesi ile mümkün olabilir. J. Paul Martin insan hakları eğitimi alanında kurucu metinlerden biri olan "Human Rights- Education for What?" (1987) isimli yazısında insan hakları eğitiminin en temel üç hedefi olması gerektiğini söyler: insan haklarını bir normatif değerler ve prensipler bütünü olarak çalıșmak ve anlamak; bu normların farklı kültürlerdeki etkilerini ve geçerliliklerini sorgulamak ve gerçek ihllalleri çalışarak insan haklarını savunmak adına geliştirilen stratejileri değerlendirmek. Bu hedefler insan haklarını normatif bir sistem olarak tanıtmanın ötesinde, bir politika ve aktivizm alanı olarak görmeyi de gerekli kılar. Netice olarak insan hakları alanındaki her eğitim -özellikle de yükseköğretim seviyesinde- kavramsal ve değerlere ilișkin felsefi tartıșmaların yanı sıra gündelik hayattan hakların kullanımına ve ihlaline ilişkin gerçek örneklerin değerlendirilmesini de içermek durumundadır. Örneğin Hamilton siyaset biliminde öğrencilerin insan haklarının nasıl savunulması gerektiğini en iyi gerçek örnekler üzerinden deneyimleyerek öğrendiklerini, bu şekilde kavramsal bilginin yanı sıra beceri de kazandıklarını gözlemler (1997). Benzer sorulara yanıt vermek bu çalışmanın sunduklarıyla mümkün değildir ancak yükseköğretimdeki insan hakları derslerinin içerikleri, derslerin işleniş biçimleri, öğretim üyelerinin kendi derslerini nasıl anlattıkları, öğrencilerin bu dersleri neden aldıkları, bu derslerden nasıl faydalandıkları, merkezler tarafından yürütülen projelerin alana katkıları üzerine yapılacak niteliksel çalıșmalar bu alana dair bilgimizi genișletecektir.

\section{KAYNAKÇA}

Açık, C. (2011). Ulusal insan hakları kurumları ve Türkiye örneğine eleştirel yaklaşım (Yayımlanmamış yüksek lisans tezi). Ankara Üniversitesi, Ankara.

Altıparmak, K. (2007). Türkiye'de insan haklarında kurumsallaş(ama)ma. Türkiye Barolar Birliği (Ed.), Bürokrasi ve insan hakları içinde (ss. 54-111). Ankara: TBB Yayınları.

Andreopoulous, G. J. \& Claude, R.P. (Eds.). (1997). Human rights education for the twenty-first century. Philadelphia: University of Pennsylvania Press.

Andreopoulos, G. (1997). Human rights education in the postcold war context. G.J. Andreopoulos \& R.P. Claude (Eds.), Human rights education for the twenty-first century içinde (ss. 9-20). Philadelphia: University of Pennsylvania Press.

Babül, E. (2017). Bureaucratic intimacies: Translating human rights in Turkey. Stanford: Stanford University Press.

Bağlı, M.T. \& Esen, Y. (Eds.). (2003). İnsan haklarına duyarlı ders kitapları için. İstanbul: Tarih Vakfı Yayınları.

Balcı, E. (2016). Üniversitelerin kadın sorunları araştırma ve uygulama merkezleri. Türkiye Klinikleri J PublicHealth-Special Topics, 2(2), 52-68.

Büyükkaragöz, S. \& Kesici, Ş. (1998). Demokrasi ve insan hakları eğitimi. Ankara: Türk Demokrasi Vakfı.

Can, F. (2006, 10 Mayıs). 12 üniversitede kadın çalışmaları merkezi. Bianet. Erişim adresi: https://bianet.org/bianet/kadin/78864-12-universitede-kadin-calismalari-merkezi

Coomans, F., Grünfeld, F. \& Kamminga, M. T. (Eds.). (2009). Methods of human rights research. Mortsel, Belgium: Intersentia.

Cooper, A. (2013, 3 Nisan). Why we need to protect the 'university'. The Guardian. Erişim adresi: https://www.theguardian.com/higher-education-network/blog/2013/apr/03/ university-title-protection-regents-college

Council of Europe. (2002). Compass: Manual for human rights education with young people. Erişim adresi: https://www. coe.int/en/web/compass

Çayır, K. (2003). İnsan hakları ve demokrasi kültürünün geliştirilmesi: Ders kitaplarının yazımı. M.T. Bağlı \& Y. Esen (Eds.), Ders kitaplarında insan hakları: Insan haklarına duyarlı ders kitapları için içinde (ss. 21-45). İstanbul: Türk Tarih Vakfı Yayınları.

Çayır, K. (2008). 'Teknik bir mesele' olarak insan hakları eğitimi. Liberal Düşünce, 49, 125-137. Erişim adresi: http:// www.libertedownload.com/LD/arsiv/49/09-kenan-cayirteknik-bir-mesele-olarak-insan-haklari-egitimi.pdf

Çayır, K. \& Bağlı, M.T. (2011). 'No-one respects them anyway': Secondary students' perceptions of human rights education in Turkey. Intercultural Education, 22(1), 1-14. doi: $10.1080 / 14675986.2011 .549641$

Çayır, K. (2014). "Biz" kimiz? Ders kitaplarında kimlik, yurttaşlık, haklar. İstanbul: Tarih Vakfı Yayınları.

Çilingiroğlu, N. (2001). Türkiye'de akademik düzeyde kadına yönelik kurumsallaşma, Hacettepe Toplum Hekimliği Bülteni, 20(2).

Çotuksöken, B., Erzan, A. \& Silier, O. (Eds.). (2003). Ders kitaplarında insan hakları tarama sonuçları. İstanbul: Tarih Vakfı Yayınları.

Dolanbay, H. (2016). Sosyal bilgiler öğretmen adaylarının insan hakları ve demokrasi dersine ilişkin görüşleri. Marmara Coğrafya Dergisi, 33, 135-154. doi: 10.14781/mcd.61070

Easterbrook, M.J., Kuppens, T. \& Manstead, A.S.R. (2016). The education effect: Higher educational qualifications are 
robustly associated with beneficial personal and socio-political outcomes. Social Indicators Research, 126(3), 1261-1298. doi:10.1007/s11205-015-0946-1.

Egerton, M. (2002). Higher education and civic engagement. British Journal of Sociology, 53(4), 603-620. doi: 10.1080/0007131022000021506.

Ehrlich, T. (Ed.). (2000). Civic responsibility and higher education. Pheonix, Arizona: The Oryx Press.

Elveriş, I., Jahic, G. \& Kalem, S. (2007). Mahkemede tek başına: İstanbul ceza mahkemelerinde müdafiliğin erişilebilirliği ve etkisi/Alone in the courtroom: Accessibility and impact of criminal legal aid before Istanbul court. İstanbul: İstanbul Bilgi Üniversitesi Yayınları.

Freedman, R. (2018, Ocak). Is the constant expansion of human rights consolidating or weakening their protection and respect? Expansion of the concept of human rights: Impact on rights promotion and protection toplantısında sunulan bildiri, Brüksel, Belçika. doi:10.2861/25972

Gülmez, M. (1996). Türkiye'de insan hakları eğitimi çalışmalarına toplu bakıs. Innsan Hakları Yıllığı, 1(17-18), 221-245. Ankara: TODAIE Yayınları.

Gülmez, M. (2001). İnsan hakları ve demokrasi eğitimi. Ankara: TODAIE Yayınları.

Gündoğdu, K. (2004). A case study on democracy and human rights education in an elementary school (Yayımlanmamış doktora tezi). Ortadoğu Teknik Üniversitesi, Ankara.

Gürel, D. (2016). Sınıf ve sosyal bilgiler öğretmenlerinin ilkokul 4. sınıf insan hakları, yurttaşlık ve demokrasi dersine yönelik görüşlerinin karşılıklı olarak incelenemesi. Ahi Euran Üniversitesi Kırşehir Eğitim Fakültesi Dergisi, 17(3), 641660. Erişim adresi: file:///C:/Users/skalem/Downloads/ JKEF_17_3_2016_641-660.pdf

Gürkaynak, İ., Türkeli, Y. \& Bağlı, H. (2002). Ben insanım: Öğretmen el kitabı. Illköğretim için İnsan Hakları Dizisi. Ankara: MEB Eğitimi Araştırma ve Geliştirme Dairesi.

Gürtan, K.R. \& Tüzün, G. (2005). Öğretmen ve öğrencilerin gözünden ders kitaplarında insan hakları: Anket sonuçları. istanbul: Tarih Vakfı Yayınları.

Hamilton, B. (1997). Human rights awareness and skill games in political science. G.J. Andreopoulos \& R.P. Claude (Eds), Human rights education for the twenty-first century içinde (ss. 221-235). Philadelphia: University of Pennsylvania Press.

HRE 2020. (t.y.). Erişim adresi: http://www.hre2020.org/

HRE 2020. (2015). Human rights education indicator framework: Key indicators to monitor and assess the implementation of human rights education and training. Erişim adresi: http:// www.hre2020.org/sites/default/files/Human\%20Rights\%20Education\%20Indicator\%20Framework_0.pdf

İnsan Hakları Eğitimi On Yılı Ulusal Komitesi. (1999). İnsan hakları eğitimi Türkiye programı: 1998-2007. Erişim adresi: http://www.kadinininsanhaklari.org/static/yayin/makalerapor/IHE-HREP_TR.pdf

Kalem, S. \& Akbaş, K. (2018). Türkiye'de Yükseköğretimde Insan Hakları Öğreniminin Durumu. (Yayımlanmamış rapor). Raoul Wallenberg İnsan Hakları ve İnsancıl Hukuk Enstitüsü Türkiye Programı.

Karaman Kepenekci, Y. (1999). Türkiye'de genel ortaöğretim ku- rumlarında insan hakları eğitimi (Yayımlanmamış doktora tezi). Ankara Üniversitesi, Ankara.

Karaman Kepenekci, Y. (2003). İlköğretimde insan hakları ve sorumluluk eğitimi. Kuram ve Uygulamada Eğitim Yönetimi Dergisi, 34(34), 280-299. Erişim adresi: http://dergipark.gov. tr/download/article-file/108441

Karaman Kepenekci, Y. (2005a). Citizenship and human rights education: A comparison of textbooks in Turkey and the United States. International Journal of Educational Reform, 14(1), 73-88.

Karaman Kepenekçi, Y. (2005b). A study of effectiveness of human rights education in Turkey. Journal of Peace Education, 2(1), 39-55. doi: 10.1080/1740020042000334091

Karaman Kepenekci, Y. \& Aslan, C. (2011). Ortaöğretim Türk edebiyatı ile dil ve anlatım ders kitaplarında insan hakları üzerine bir çözümleme. Turkish Studies, 6(1), 483-502. doi: 10.7827/TurkishStudies.1952

Kuçuradi, İ. (2018). İnsan hakları: Kavramları ve sorunları. Ankara: Türkiye Felsefe Kurumu Yayınları.

Ma, J., Pender, M. \& Welch, M. (2016). Education pays: The benefits of higher education for individuals and society. Trends in Higher Education Series. The College Board. Erişim adresi: https://trends.collegeboard.org/sites/default/files/education-pays-2016-full-report.pdf

Maran, R. (1997). Teaching human rights in the universities: Paradoxes and prospects. G.J. Andreopoulos \& R.P. Claude (Eds), Human rights education for the twenty-first century içinde (ss. 194-208). Philadelphia: University of Pennsylvania Press.

Martin, J.P. (1987). Human rights-education for what? Human Rights Quarterly, 9, 414-422. Erişim adresi: file:///C:/Users/ skalem/Downloads/JPaulMartinHumanRightsEdu\%20(1). pdf

McMahon, W.W. (2009). Higher learning, greater good: The private and social benefits of higher education. Baltimore: The Johns Hopkins University Press.

Özvarış, Ş. \& Akın, A. (2003). Üniversitelerin kadın sorunları araştırma ve uygulama merkezleri. Ankara: Hacettepe Üniversitesi Kadın Sorunları Araştırma ve Uygulama Merkezi Yayınları. Erişim adresi: http://www.huksam.hacettepe. edu.tr/Turkce/SayfaDosya/universitelerin_kadin_sorunlari.pdf

Sarıtaş, E. (2013). Güncel feminist tartışmalar: Toplumsal cinsiyet ve kadın çalışmaları anabilim dalı öğretim üyelerinin kitapları üzerine bir inceleme. Mülkiye Dergisi, 37 (4), 193 222.

Savaş, G., Ertan, S. \& Yol, F. (2018). Türkiye'deki üniversitelerin kadın araştırmaları merkezleri profili araştırması. Elektronik Sosyal Bilimler Dergisi, 17 (68), 1527-1547.

Sen, A. \& Starkey, H. (2017). The rise and fall of citizenship and human rights education in Turkey. Journal of Social Science Education, 16(4), 85-97. doi: 10.4119/UNIBI/jssev16-i4-1689

Turan, R. (Ed.). (2017). İnsan hakları ve demokrasi eğitimi: Öğretmen adayları ve öğretmenler için. Ankara: PEGEM Yayıncılık. doi: 10.14527/9786052410639

Uluslararası Af Örgütü. (t.y.). Erişim adresi: https://www.amnesty.org/en/human-rights-education/ 
Uluslararası Af Örgütü. (2002). İlk adım: İnsan hakları eğitimine başlangıç için el kitabı (î. Üstüner \& G. Gürsoy, Çev.). Erişim adresi: http://ihea.net.tr/images/kutuphane/insanhaklariicinilkadim648.pdf

Uluslararası Af Örgütü. (2010). Her insan ÖZGÜR DOĞAR: Insan olmaktan kaynaklanan haklarımız üzerine. Erişim adresi: http://nehakkinvar.org/uploads/Docs/1439_herinsanozgurdogar729.pdf

United Nations Educational, Scientific and Cultural Organization. (1968). Some suggestions on teaching about human rights. Erişim adresi: http://unesdoc.unesco.org/images/0005/000564/056409eo.pdf

United Nations Educational, Scientific and Cultural Organization. (1987). Human rights: An ethical and civic education for our time. Human Rights Teaching, 6, 175-184.

United Nations Office of the High Commissioner for Human Rights. (t.y.a). Summary of national initiatives undertaken within the Decade for Human Rights Education (1995-2004). Erişim adresi: https://www.ohchr.org/EN/Issues/Education/Training/Pages/Initiatives.aspx

United Nations Office of the High Commissioner for Human Rights. (t.y.b). World Programme for Human Rights Education (2005-ongoing). Erişim adresi: https://ohchr.org/EN/ Issues/Education/Training/Pages/Programme.aspx

United Nations Office of the High Commissioner for Human Rights. (t.y.c). Human rights education and training. Erişim adresi: https://www.ohchr.org/EN/Issues/Education/Training/Pages/HREducationTrainingIndex.aspx

Ünal, F. (2012). Ortaokul 8. sınıf vatandaşlık ve demokrasi eğitimi öğretim programı ve ders kitaplarında insan hakları üzerine bir çözümleme. Bartın Üniversitesi Eğitim Fakültesi Dergisi, 1(1), 110-127. Erişim adresi: http://dergipark.gov.tr/ download/article-file/43549

Yükseköğretim Kurulu. (t.y.). Erişim adresi: http://www.yok.gov. tr/web/guest/universitelerimiz 